\title{
Numerical Study on the Effect of Fuel Rich n-Heptane on In-Cylinder Fuel Reforming Characteristics in an HCCI Engine
}

\author{
Weijian Zhou $\left(\mathbb{D}\right.$, Song Zhou $\left(\mathbb{D}\right.$, Hongyuan Xi ${ }^{\mathbb{D}}$, Majed Shreka ${ }^{(D)}$, and Zhao Zhang $(\mathbb{D}$ \\ College of Power and Energy Engineering, Harbin Engineering University, Harbin 150001, China \\ Correspondence should be addressed to Song Zhou; songzhouheu@163.com and Hongyuan Xi; xhy_9999@163.com
}

Received 7 July 2021; Revised 10 September 2021; Accepted 25 September 2021; Published 13 October 2021

Academic Editor: Valeria Di Sarli

Copyright (c) 2021 Weijian Zhou et al. This is an open access article distributed under the Creative Commons Attribution License, which permits unrestricted use, distribution, and reproduction in any medium, provided the original work is properly cited.

\begin{abstract}
The effect of in-cylinder fuel reforming on an n-heptane homogenous charge compression ignition engine has been studied. A dedicated cylinder without a complex control system is proposed for fuel enrichment reforming, which can provide part of the power for the engine. The effects of different reforming species on engine performance and chemical reaction have been simulated by a numerical study. By comparing the combustion characteristics of $n$-heptane with different equivalence ratios in the reformer cylinder, the optimal n-heptane equivalence ratio has been determined. The enrichment of n-heptane produces sufficient hydrogen $\left(\mathrm{H}_{2}\right)$ and carbon monoxide $(\mathrm{CO})$, while the hydrocarbon content of the reforming species was low. It was found that the addition of reforming species retards the combustion phase of $n$-heptane, thereby providing a means of controlling engine performance. In addition, the laminar flame speed and the adiabatic flame temperature of $n$-heptane increased by adding $\mathrm{H}_{2}$ and $\mathrm{CO}$. Fuel reforming reduced the emission of ethylene, propyne, allene, propylene, butadiene, and nitrogen oxide, but it increased the emissions of acetylene and CO. Moreover, chemical, dilution, and thermodynamic effects of the reforming gas have been studied. The results showed that the chemical effect of the reforming species was less significant than the dilution and thermodynamic effects. These simulation results showed that in-cylinder fuel reforming can effectively improve engine performance and thereby reduce emissions.
\end{abstract}

\section{Introduction}

The internal combustion engine (ICE) has superior power performance, economy, and reliability and so rapidly became the main vehicular power source. However, strict regulations and energy shortage are urgent problems to be solved in ICE research [1-3]. At present, there are many strategies for improving energy efficiency and solving environmental problems. These strategies include homogenous charge compression ignition (HCCI), Reactivity Controlled Compression Ignition, and Partially Premixed Compression Ignition [4-6], as well as the use of alternative fuels, such as natural gas [7] and biodiesel [8]. HCCI engine combustion involves premixed homogenous compression ignition. Since the HCCI engine adopts compression auto-ignition, the compression ratio can be greatly increased, which has the potential to improve combustion efficiency and reduce fuel consumption, thereby ensuring extremely low nitrogen oxide (NOx) and particulate matter emissions $[9,10]$. In fact, the essential difference between these strategies and traditional internal combustion engines is that the reaction path of fuel combustion is modified by changing the initial conditions.

Coskun et al. [11] numerically studied the effect of secondary injection on the combustion and emissions of an HCCI engine. If secondary injection was delayed, hydrocarbon emissions would increase. Zheng et al. [12] studied the combustion and emission characteristics of an $n$-butanol HCCI engine. They found that $n$-butanol HCCI combustion has advantages of ultra-low $\mathrm{NO}_{x}$ and soot emissions. It is widely accepted that because the combustion phase of HCCI combustion mode is difficult to control, it must be mainly controlled by chemical kinetics. Therefore, an appropriate fuel is needed to improve the combustion and emissions of an HCCI engine. Guo et al. [13] pointed out that identifying a fuel with a relatively low cetane number and short 
combustion time is key to improving the combustion and emissions of an HCCI engine. Therefore, more researchers are seeking to optimize the performance and emissions of the HCCI engine by means of fuel reforming [14].

For the ICE, fuel reforming can generally be divided into two types. The first method uses a reforming catalyst unit for fuel reforming [15]. For example, Sail et al. [16] carried out catalytic reforming of ethanol fuel to obtain a mixture containing $\mathrm{H}_{2}, \mathrm{CO}$, and methane and blended this mixture with ethanol diesel fuel, which improved fuel economy and reduced emissions. Geng et al. [17] established a low-temperature fuel reforming (LTR) system to study the effect of $\mathrm{n}$-heptane reforming species on combustion characteristics. They found that LTR combustion mode reduces soot generation, prolongs the ignition delay time, makes the distribution of $\mathrm{OH}$ free radical more uniform, and improves engine combustion performance. Yao et al. [18] used a palladium catalyst to catalyze methanol-reforming in a spark ignition (SI) engine exhaust pipe. Their results showed that methanol-reforming can improve the fuel economy of the SI engine. Yap et al. [19] studied the effect of catalytic reforming on the HCCI engine and found it to have a stabilizing effect. However, catalytic reforming increases the burden on the engine, and catalyst aging and poisoning also restrict the use of catalytic reforming technology. The second reforming method is in-cylinder reforming within the engine [20]. For example, Alger et al. [21, 22] developed a dedicated exhaust gas recirculation (D-EGR) working mode application for gasoline engines. In this study, exhaust with rich stoichiometric mixtures of fuels from one cylinder of a four-cylinder gasoline engine was directly discharged into the intake manifold, which produced a constant EGR level of $25 \%$. The results showed that this mode can improve fuel efficiency and reduce emission. In order to improve the performance of an SI natural gas engines, Zhu et al. [23, 24] studied the effect of the fuel reforming in-cylinder on its combustion. It was found to reduce emissions, while also improving fuel economy. The main components of the reforming gas were $\mathrm{H}_{2}, \mathrm{CO}, \mathrm{CO}_{2}$, and $\mathrm{N}_{2}$. The process was termed in-cylinder thermochemical fuel reforming and was similar to the operation mode of the D-EGR concept. Wang et al. [25] numerically studied the effect of low-temperature integration products on HCCI engine performance. They proposed a flexible cylinder engine (FCE) working mode applicable to an HCCI engine. Their simulation results showed that FCE improved combustion and reduced emissions. Willand et al. [26] developed a strategy of negative valve overlap (NVO) in-cylinder fuel reforming. Urushihara et al. [27] used this concept to realize fuel reforming in a gasoline HCCI engine. They proposed a new injection strategy that only part of the fuel is injected into the NVO region, with the rest being injected in the intake stroke. Their research results indicated that this method could effectively reduce NOx emissions from the whole engine and broaden the operation range of HCCI combustion.

In this study, a fuel reforming mode for an HCCI engine with in-cylinder fuel enrichment is proposed. As shown in Figure 1, the fuel is enriched in one cylinder of the engine, termed the reforming cylinder. In-cylinder fuel reforming is realized by in-cylinder fuel enrichment, and then all of the reforming gas is discharged into the intake manifold. The reforming gas contains $\mathrm{H}_{2}$ and $\mathrm{CO}$, which is helpful in improving engine performance and reducing emissions. Unlike D-EGR, which focuses on the spark plug ignition gasoline engine, this study concerns the HCCI diesel engine. In contrast to the work of Wang et al. [25], the designed dedicated cylinder is mainly used to transform diesel fuel and to provide part of the power for the engine without a complex control system, which saves on design costs. Compared with other reforming strategies, it also avoids an additional reforming unit (reaction catalytic unit) and saves engine layout space. Moreover, other fuels can also be used as the fuel of an HCCI engine, besides diesel. The main reforming species are $\mathrm{H}_{2}$ and $\mathrm{CO}$, which serve to improve combustion and reduce emission. All reforming species and new fuel are mixed with air before entering the cylinder, in which they burn evenly. The addition of reforming species changes the composition of the initial fuel and the reaction path of fuel combustion. Because n-heptane has a high cetane number and good chemical activity, it can be used as a substitute for diesel [28]. For this study, n-heptane was selected as the engine fuel, and the influence of fuel reforming on the HCCI engine has been studied through numerical simulation. We have mainly studied the fuel reforming phenomenon of the HCCI engine from the viewpoint of chemical dynamics.

\section{Simulation Methods}

The detail chemical kinetic mechanism of n-heptane version 3.1 has been studied at the Lawrence Livermore National Laboratory [29], which included 654 species and 2827 reactions. The detailed mechanism included the possible free radicals, stable reactants, and products in the process of n-heptane oxidation and allows for quantitative prediction of the experimental results and simulation of the combustion process of alternatives to diesel fuel in an HCCI. In addition, in order to analyze the influence of fuel reforming on NOx emission from an HCCI engine, a reduced NOx mechanism consisting of 4 species and 13 reactions [30] was appended to the detailed chemical kinetic mechanism of $\mathrm{n}$-heptane for the prediction of NOx emissions.

All calculation data are based on the closed internal combination HCCI engine model of ANSYS CHEMKIN 17.0 [31]. The engine studied is an HCCI engine for experimental study in reference [32]. The engine specifications are listed in Table 1. Parameters of the two different operating conditions are listed in Table 2. Of the four cylinders of the engine, one is a reforming cylinder, while the other three are normal cylinders. The reforming species are mixed with new fuel and then injected into the engine. In order to study the effects of fuels with different equivalence ratios on the performance of reforming cylinder and the reforming products, equivalence ratios in the reforming cylinder were varied in the range $1.0-1.7$, with that of the normal cylinder set at 0.6. The initial temperature and pressure of the reforming cylinder with n-heptane enrichment were set at $350 \mathrm{~K}$ and $1 \mathrm{~atm}$, respectively. The simulation process is 


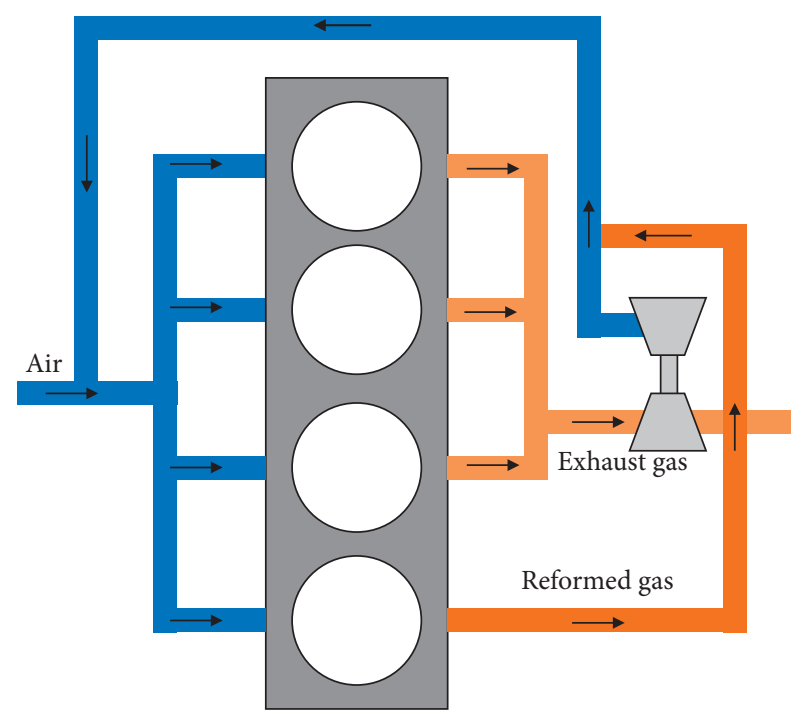

FIGURE 1: Schematics representation of the fuel reforming system in an HCCI engine.

considered as the period from the closing time of the inlet valve to the opening time of the exhaust valve, and the initial fuel of the normal cylinder is the mixture of new fuel and reforming gas.

The closed homogenous batch reactor, premixed laminar flame speed calculation, and the chemical and phase equilibrium calculator models of the ANSYS CHEMKIN 17.0 [31] software package were used to simulate the effects of reforming gas on ignition delay, laminar flame speed, and adiabatic flame temperature of $\mathrm{n}$-heptane. In the simulation of ignition delay, the initial pressure was set at $40 \mathrm{bar}$ considering the cylinder pressure of the HCCI engine. The ignition delay time was defined as the time at which the initial temperature of the fuel increases by $400 \mathrm{~K}$. In the simulation of laminar flame speed, the initial temperature was $450 \mathrm{~K}$, and the initial pressure was $1 \mathrm{~atm}$. When simulating adiabatic flame temperature, the initial condition was the same as that of laminar flame velocity. All of the simulated initial fuels were a mixture of $n$-heptane and reforming gas and were mixed according to the calibrated mixing ratio.

\section{Results and Discussion}

3.1. The Enriching Fuel Reforming Process. In the current research, $\mathrm{n}$-heptane fuel is enriched in the reforming cylinder. Thus, equivalence ratio is an important parameter affecting $n$-heptane combustion. Figure 2 shows the pressure and temperature profiles of the reforming cylinder at different $\mathrm{n}$-heptane equivalence ratios. Since the exhaust valve of the HCCI engine is opened at 125 after the top dead center (ATDC), the selected reforming species entering the normal cylinder is the reforming gas at 125 ATDC. $\Phi_{F R}$ is the equivalence ratio of $\mathrm{n}$-heptane in the reforming cylinder of the HCCI engine. As can be seen from Figure 2(a), the combustion phase is gradually delayed with the increase of $\mathrm{n}$-heptane equivalence ratio. The peak pressure in the cylinder is maximized when the equivalence ratio is 1.2 and
TABLE 1: Engine specifications.

\begin{tabular}{lc}
\hline Parameters & Value \\
\hline Bore $(\mathrm{mm})$ & 115 \\
Stroke $(\mathrm{mm})$ & 115 \\
Connecting rod length $(\mathrm{mm})$ & 210 \\
Compression ratio & 17 \\
Engine speed (r/min) & 1400 \\
Inlet valve closing (IVC) & 135 BTDC \\
Exhaust valve opening (EVO) & 125 ATDC \\
\hline
\end{tabular}

TABle 2: Operation conditions of HCCI engine.

\begin{tabular}{lcc}
\hline & Reforming cylinder & $\begin{array}{c}\text { Normal } \\
\text { cylinders }\end{array}$ \\
\hline Equivalence ratio & $1.0-1.7$ & 0.6 \\
Initial gas temperature (K) & 350 & 350 \\
Initial gas pressure (atm) & 1 & 1 \\
Fuel & n-heptane & n-heptane \\
\hline
\end{tabular}

then gradually decreases. As can be seen from Figure 2(b), the peak temperature in the cylinder is maximized when the equivalence ratio is 1.1 and then gradually decreases. This is due to the reduction of oxygen concentration, incomplete combustion of n-heptane, and reduction of total heat release. At the same time, due to the high heat capacity of n-heptane, the heat capacity of the whole system increases. The combined effect of these factors leads to an increase in ignition delay and a retardation of the combustion phase with increasing $\mathrm{n}$-heptane equivalence ratio. It also leads to a downward shift of the temperature curve of the reforming cylinder.

3.2. Reformed Gas Composition. Figure 3 shows the changes in the mole fraction of the reforming gas in the reforming cylinder with different $\mathrm{n}$-heptane equivalence ratios. It can be seen from Figure 3 that the main species in the reforming cylinder are $\mathrm{H}_{2}, \mathrm{CO}, \mathrm{CO}_{2}, \mathrm{O}_{2}$, and $\mathrm{H}_{2} \mathrm{O} . \mathrm{N}_{2}$ is not included in the present analysis, because it does not participate in the chemical reaction. When the $\mathrm{n}$-heptane equivalence ratio is less than 1.3, the hydrogen content in the reforming gas is very low. With the increase of $n$-heptane equivalence ratio, the contents of $\mathrm{H}_{2}$ and $\mathrm{CO}$ gradually increase, while the contents of $\mathrm{CO}_{2}$ and $\mathrm{H}_{2} \mathrm{O}$ gradually decrease. This shows that $\mathrm{n}$-heptane reforming takes place in the reforming cylinder. The decomposition of $\mathrm{n}$-heptane mainly occurs before TDC. With the increase of the equivalence ratio, the time of reforming is obviously delayed. Hence, it is very important to choose an appropriate $\mathrm{n}$-heptane equivalence ratio.

Figure 4 shows the mole fractions of $\mathrm{H}_{2}, \mathrm{CO}, \mathrm{CO}_{2}, \mathrm{H}_{2} \mathrm{O}$, $\mathrm{O}_{2}$, and $\mathrm{n}$-heptane at different $\mathrm{n}$-heptane equivalence ratios of the HCCI engine at 125 ATDC. It can be seen that when the equivalence ratio is 1.0 , the $\mathrm{H}_{2}$ content is basically 0 , and with the increase of equivalence ratio, the $\mathrm{O}_{2}$ content is close to 0 . When the equivalence ratio of $\mathrm{n}$-heptane is greater than 1.5 , the content thereof in the reforming species gradually 


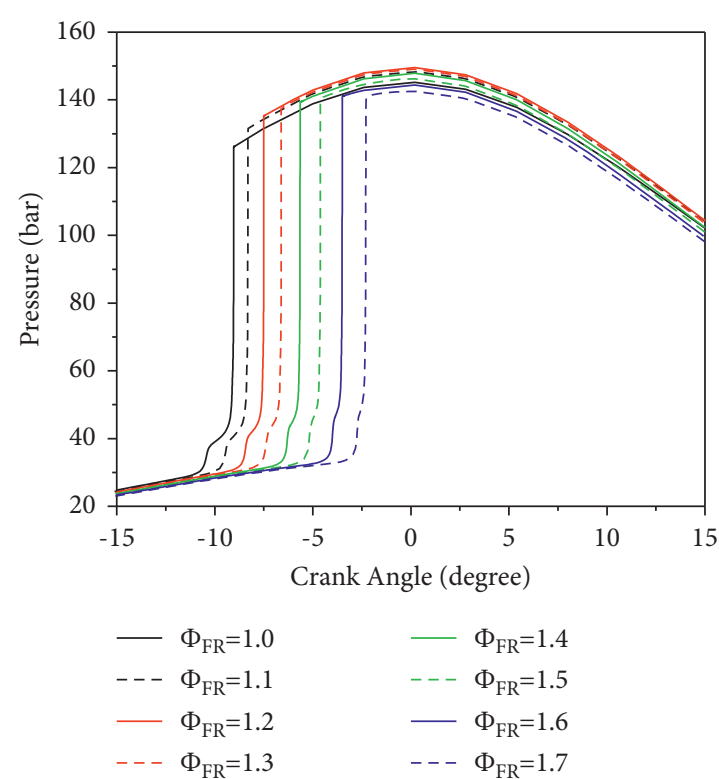

(a)

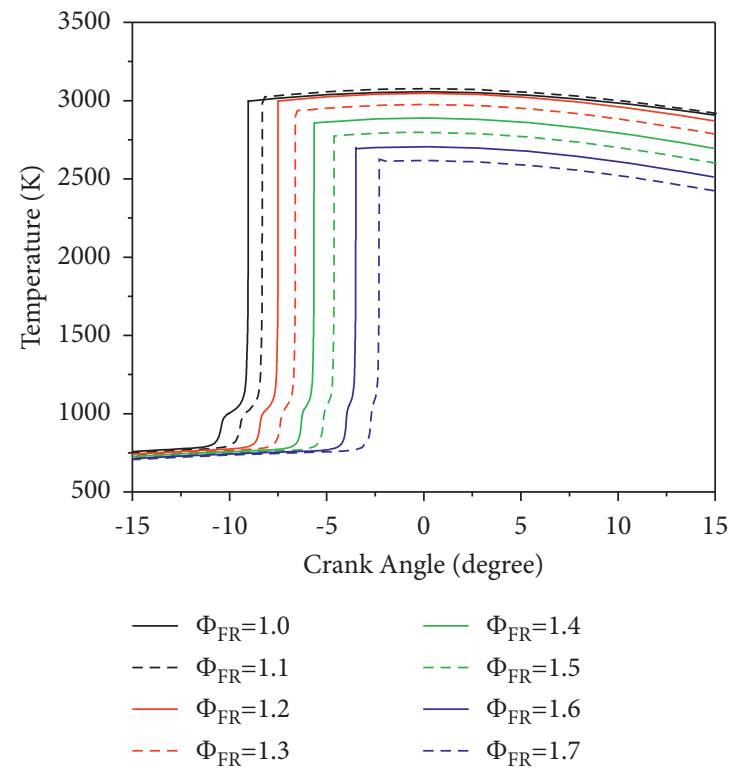

(b)

Figure 2: Pressure and temperature profiles of the reforming cylinder at different $n$-heptane equivalence ratios.

increases. Considering that the contents of $n$-heptane and oxygen in the reforming gas should be minimized, and in view of the cylinder pressure and temperature curves in Figure 2, an n-heptane equivalence ratio of 1.5 was selected as optimal for the reforming cylinder. The reforming component at 125 ATDC was selected as the reforming gas of the HCCI engine. The mole fraction of $n$-heptane in the reforming cylinder was reduced from $2.78 \times 10^{-2}$ to $1.07 \times 10^{-37}$. It can be seen that $\mathrm{n}$-heptane is reformed in the reforming cylinder, and almost all of it is converted to reforming species. In the reforming product, the mole fractions of $\mathrm{H}_{2}, \mathrm{CO}, \mathrm{CO}_{2}$, and $\mathrm{H}_{2} \mathrm{O}$ are $6.45 \times 10^{-2}$, $1.08 \times 10^{-1}, 5.67 \times 10^{-2}$, and $1.23 \times 10^{-1}$, respectively. Because the mole fractions of other reforming species are very low, they can be ignored.

\subsection{Effects of Enriching Fuel of the Engine}

3.3.1. Effects of Reformed Gas on the Engine. When the reforming gas is added to the normal cylinder, the initial fuel becomes a mixture of new fuel and reforming species. Figure 5 compares the pressure and temperature profiles of the normal cylinder with different reforming species and the simulation results of the normal cylinder burning pure heptane. It can be seen that, with the addition of CO, the peak pressure and peak temperature in the cylinder increase, and the combustion phase is advanced. When $\mathrm{H}_{2}$ is added, the peak pressure and peak temperature increase, but the combustion phase is retarded. This is qualitatively consistent with the results of Guo et al. [13] and konsreeparp et al. [33] on the effect of $\mathrm{H}_{2}$ enrichment on HCCI combustion. The addition of $\mathrm{CO}$ and $\mathrm{H}_{2}$ increases the peak cylinder pressure and temperature, because both $\mathrm{H}_{2}$ and $\mathrm{CO}$ promote combustion in the cylinder. However, when all reforming species are added, the peak pressure and temperature in the cylinder decrease, and the combustion phase is retarded. This is because the addition of reforming species reduces the charge temperature in the cylinder and extends the ignition delay time of the fuel. The temperature results are similar to the pressure results.

Adding different reforming species to a normal cylinder fueled with pure heptane may cause combustion phase changes due to chemical, dilution, and thermodynamic effects. In order to analyze these effects, Guo et al. [13] and Neshat et al. [34] proposed a dummy species to analyze the relative contribution of chemical, dilution, and thermodynamic effects of hydrogen addition to the delay of combustion phase. Therefore, the chemical, dilution, and thermodynamic effects of reforming species were calculated by methods used in previous studies. Two new species $\mathrm{CO} *$ and $\mathrm{H}_{2} *$ with the same thermodynamic data as $\mathrm{CO}$ and $\mathrm{H}_{2}$ are proposed. $\mathrm{CO} *$ and $\mathrm{H}_{2} *$ do not participate in any chemical reaction. When $\mathrm{CO} *$ and $\mathrm{H}_{2} *$ replace $\mathrm{CO}$ and $\mathrm{H}_{2}$, the influence of chemical reaction of $\mathrm{CO}$ and $\mathrm{H}_{2}$ will be eliminated, so the influence of dilution and thermodynamic effects can be analyzed in terms of $\mathrm{CO} *$ and $\mathrm{H}_{2} *$. In this study, the chemical effect was considered alone, while the dilution effect and the thermodynamic effects were considered together. It is widely accepted that $\mathrm{OH}$ radicals affect the ignition delay time. Therefore, we studied the mole fraction distribution of $\mathrm{OH}$ radicals in the presence of different reforming species, and the results are shown in Figure 6. In Figure 6, n-heptane + all species $*$ means that $\mathrm{H}_{2}$ and $\mathrm{CO}$ are replaced by $\mathrm{H}_{2} *$ and $\mathrm{CO} *$. The addition of $\mathrm{CO}$ and $\mathrm{H}_{2}$ increases the mole fraction of $\mathrm{OH}$, as was also found in section 3.3.2. When adding all the species of reforming gas, the chemical effect is far less than the thermodynamic and dilution effects. This is because the species of reforming gas include $\mathrm{CO}_{2}$ and $\mathrm{H}_{2} \mathrm{O}$, which will produce a dilution effect upon the intake of air into the HCCI engine, inhibiting 


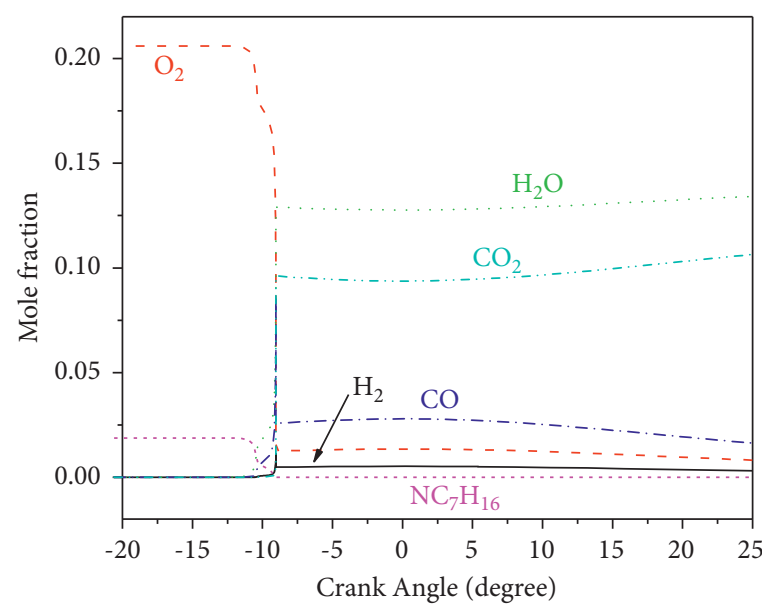

(a)

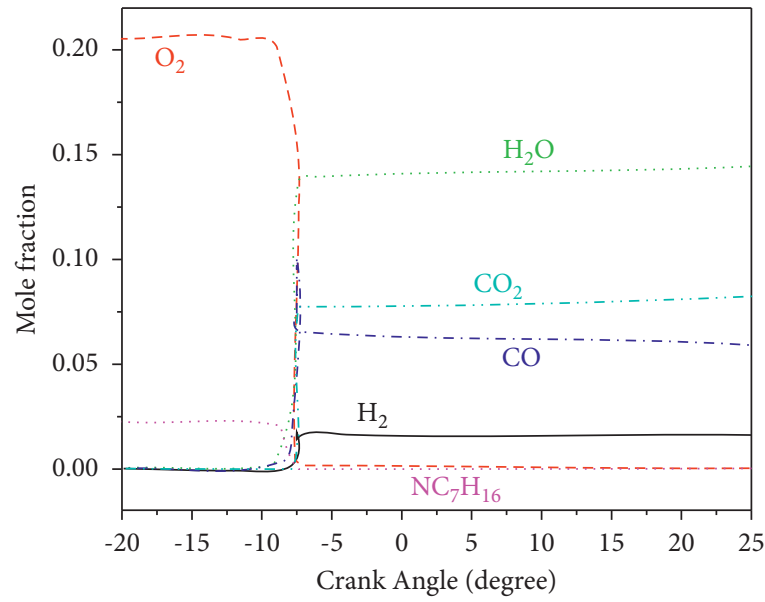

(c)

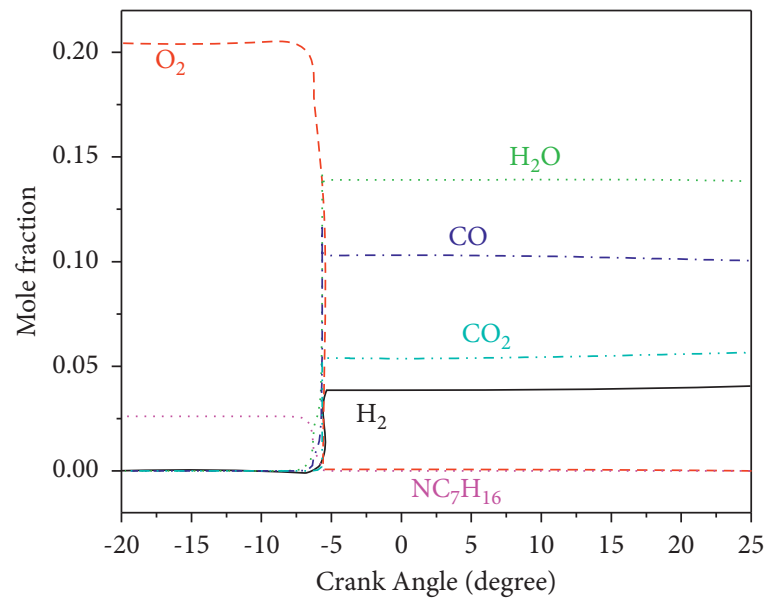

(e)

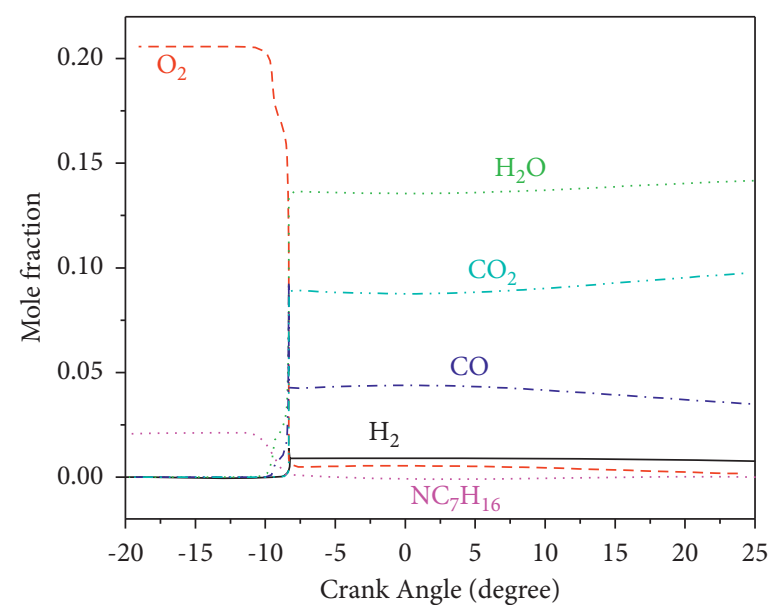

(b)

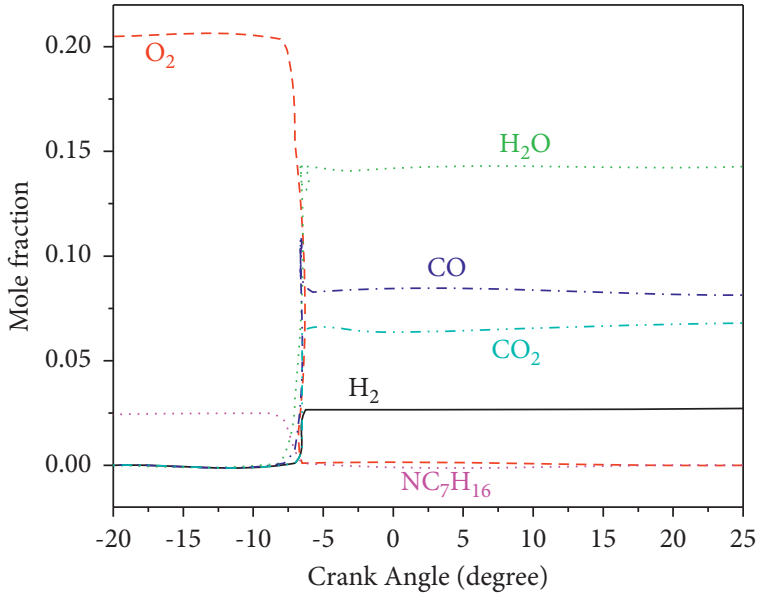

(d)

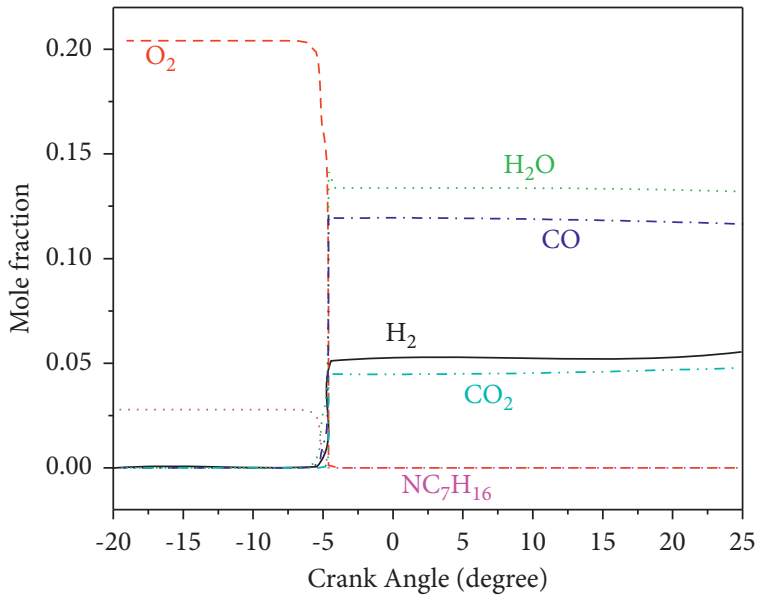

(f)

FIgURE 3: Continued. 


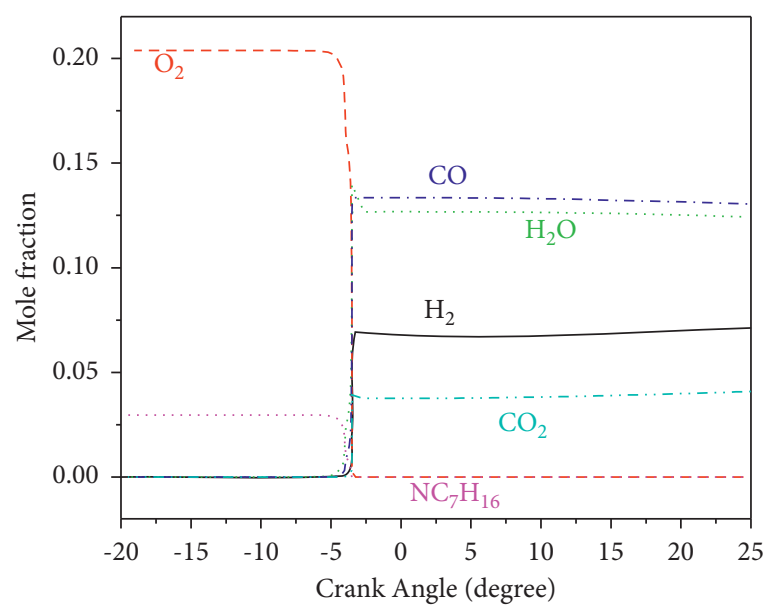

(g)

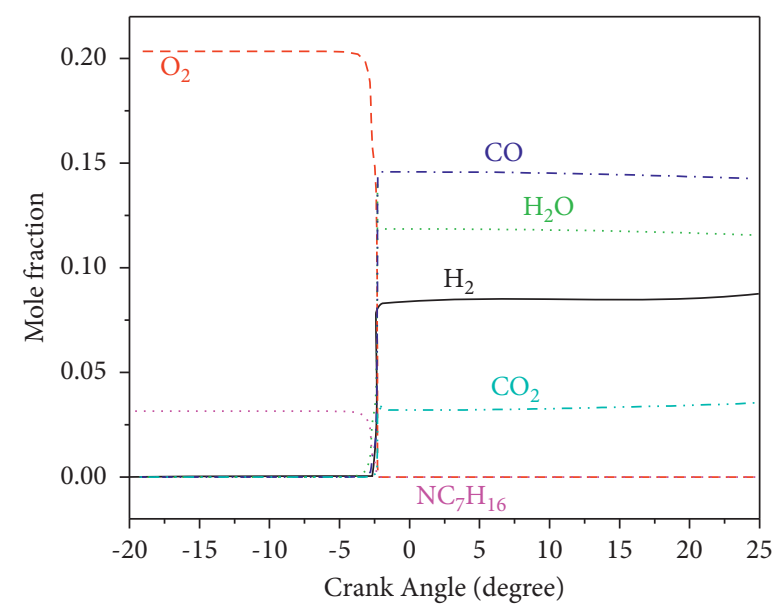

(h)

Figure 3: Variations in the mole fraction of the reforming species at different n-heptane equivalence ratios. (a) $\Phi_{F R}=1.0$. (b) $\Phi_{F R}=1.1$. (c) $\Phi_{F R}=1.2$. (d) $\Phi_{F R}=1.3$. (e) $\Phi_{F R}=1.4$. (f) $\Phi_{F R}=1.5$. (g) $\Phi_{F R}=1.6$. (h) $\Phi_{F R}=1.7$.

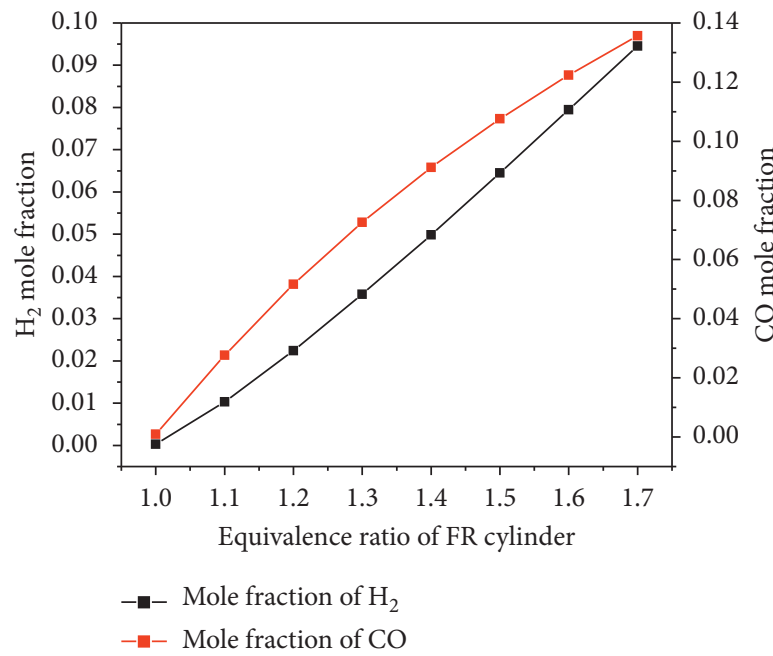

(a)

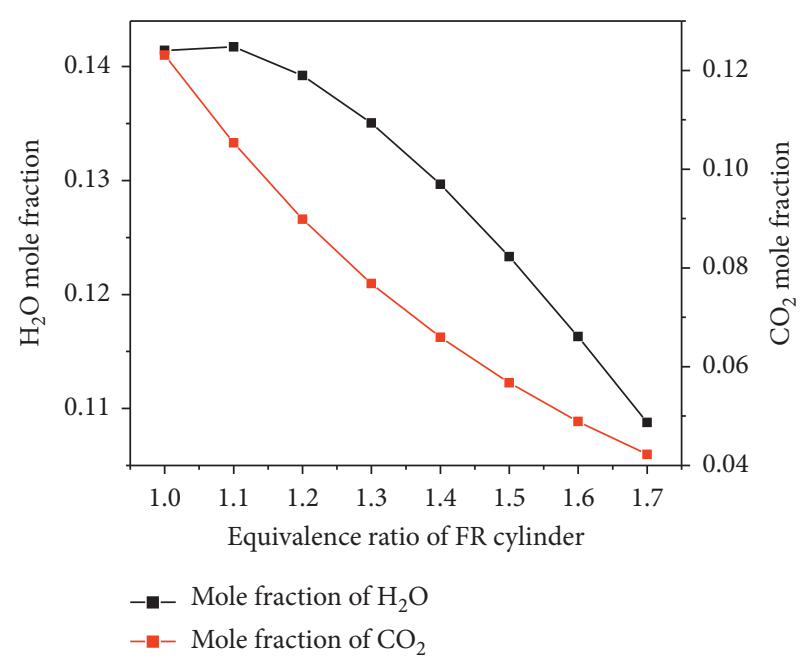

(b)

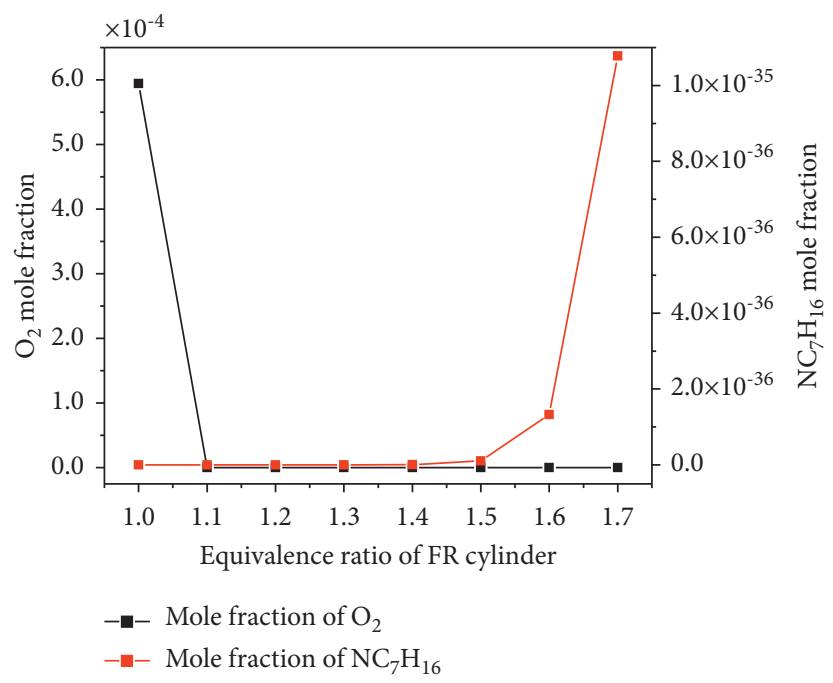

(c)

Figure 4: Mole fractions of $\mathrm{H}_{2}, \mathrm{CO}, \mathrm{CO}_{2}, \mathrm{H}_{2} \mathrm{O}, \mathrm{O}_{2}$, and n-heptane at different n-heptane equivalence ratios for the $\mathrm{HCCI}$ engine at 125 ATDC. 


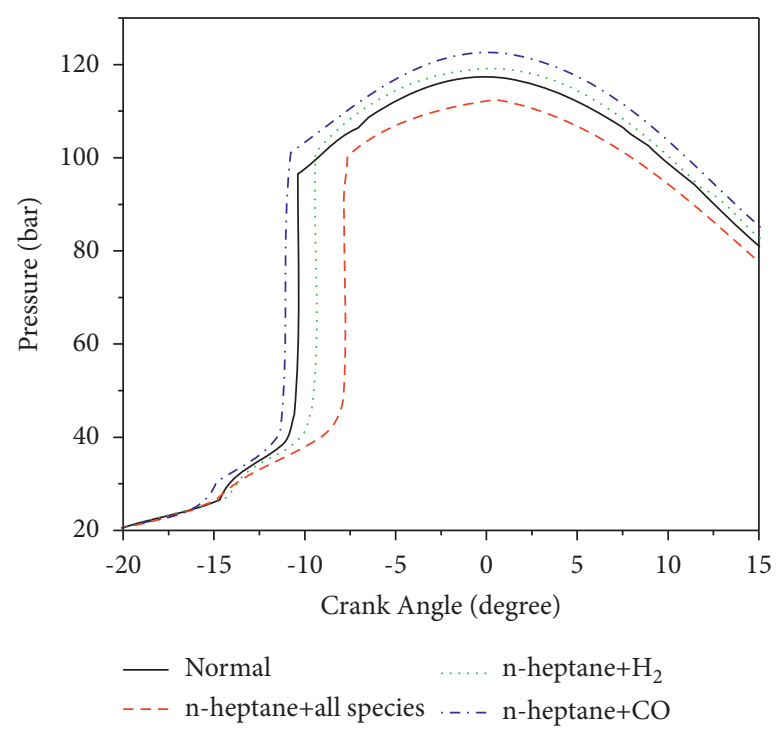

(a)

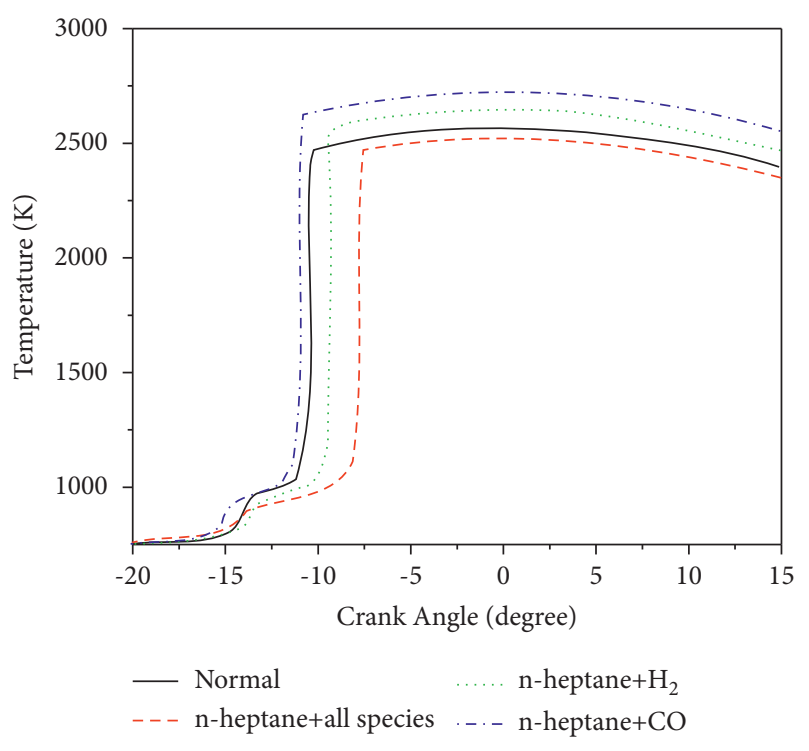

(b)

FIgURE 5: Comparisons of normal cylinder pressure and temperature with different reforming species.

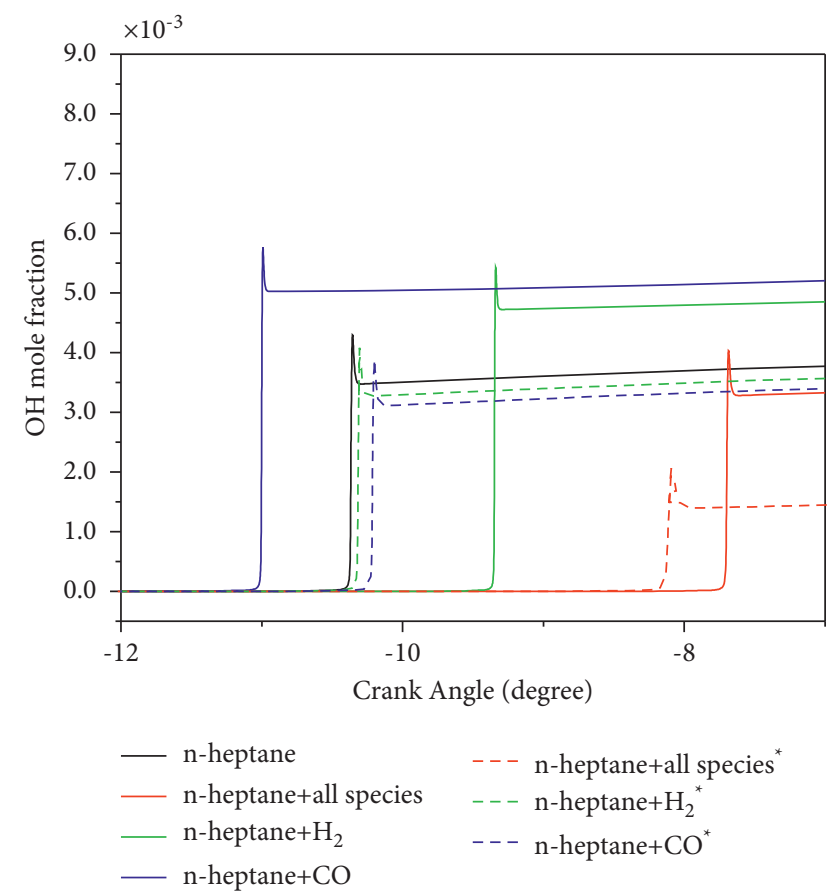

Figure 6: Distributions of $\mathrm{OH}$ radicals in different reforming mixtures.

the oxidative decomposition of n-heptane, and delaying the combustion phase. However, the chemical effects of $\mathrm{H}_{2}$ and $\mathrm{CO}$ are significantly greater than the dilution and thermodynamic effects. $\mathrm{H}_{2}$ and $\mathrm{CO}$ are less than the dilution and thermodynamic effects of all species. The dilution and thermodynamic effects of $\mathrm{CO}$ are greater than $\mathrm{H}_{2}$. Whereas $\mathrm{H}_{2}$ participates in the low-temperature reaction of n-heptane, CO does not. It can clearly be seen from Figure 6 that the mole fraction of $\mathrm{OH}$ radical decreases due to addition of the virtual component. The addition of $\mathrm{H}_{2}$ delays the formation of $\mathrm{OH}$ radical. This is because, in the oxidation process of $n$-heptane, the first low-temperature oxidation reaction occurs according to the simplified reaction pathway shown in Figure 7. n-Heptane mainly undergoes hydrogen abstraction through low-temperature reactions such as $\mathrm{RH}+\mathrm{H}=\mathrm{R}+\mathrm{H}_{2}, \mathrm{RH}+\mathrm{O}_{2}=\mathrm{R}+\mathrm{HO}_{2}, \mathrm{RH}+\mathrm{OH}=\mathrm{R}+\mathrm{H}_{2} \mathrm{O}$, where $\mathrm{RH}$ represents $n-\mathrm{C}_{7} \mathrm{H}_{16}, \mathrm{R}$ represents $\mathrm{C}_{7} \mathrm{H}_{15}-\mathrm{n}$ radicals, Q represents $\mathrm{C}_{7} \mathrm{H}_{14}-\mathrm{n}$ radicals, and KET denotes ketohydroperoxide. When $\mathrm{H}_{2}$ is added to the normal cylinder, it will produce dilution and thermodynamic effects and reduce the oxygen concentration. $\mathrm{H}_{2}$ also inhibits the low temperature reaction of n-heptane $\mathrm{RH}+\mathrm{H}=\mathrm{R}+\mathrm{H}_{2}$, and $\mathrm{H}_{2}$ competes with other radicals to consume $\mathrm{OH}$ according to $\mathrm{H}_{2}+\mathrm{OH}=\mathrm{H}_{2} \mathrm{O}+\mathrm{H}$, which inhibits the low-temperature reaction of $\mathrm{n}$-heptane $\mathrm{RH}+\mathrm{OH}=\mathrm{R}+\mathrm{H}_{2} \mathrm{O}$. Therefore, the addition of $\mathrm{H}_{2}$ will lead to a retardation of the combustion phase, which is similar to the results of Guo et al. [13]. The $\mathrm{CO}$ content in the reforming gas is higher than that of $\mathrm{H}_{2}$ and there will be a certain dilution effect when $\mathrm{CO}$ is added. Nevertheless, $\mathrm{CO}$ will first react with oxygen according to $\mathrm{CO}+\mathrm{O}_{2}=\mathrm{CO}_{2}+\mathrm{O}$, thereby producing $\mathrm{O}$ radicals, promoting the oxidative decomposition of n-heptane, and advancing the combustion phase.

3.3.2. Combustion Characteristics. In order to analyze the influence of different reforming species on ignition delay time, Figure 8 shows the ignition delay time of n-heptane and its reforming species mixture. It can be seen that the simulation results of the ignition delay time of the n-heptane + all species mixture are quite different from those for pure heptane when all species are added, which is mainly due to the dilution and thermodynamic effects of the reforming species. For the mixture of $\mathrm{n}$-heptane and $\mathrm{H}_{2}$, it can be seen that the ignition delay increased, whereas it decreased 


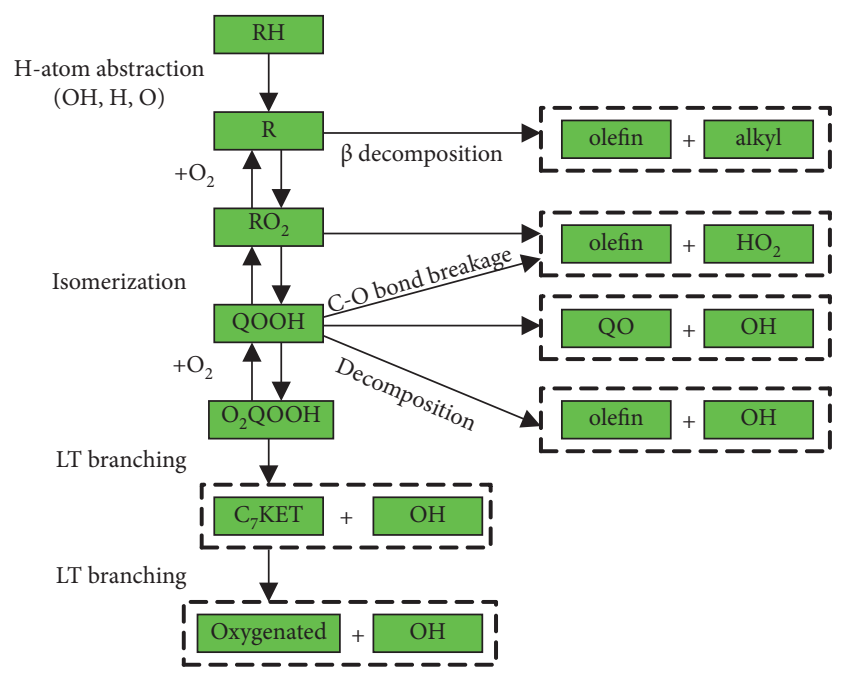

FIgURE 7: Simplified reaction pathways of $n$-heptane oxidation.

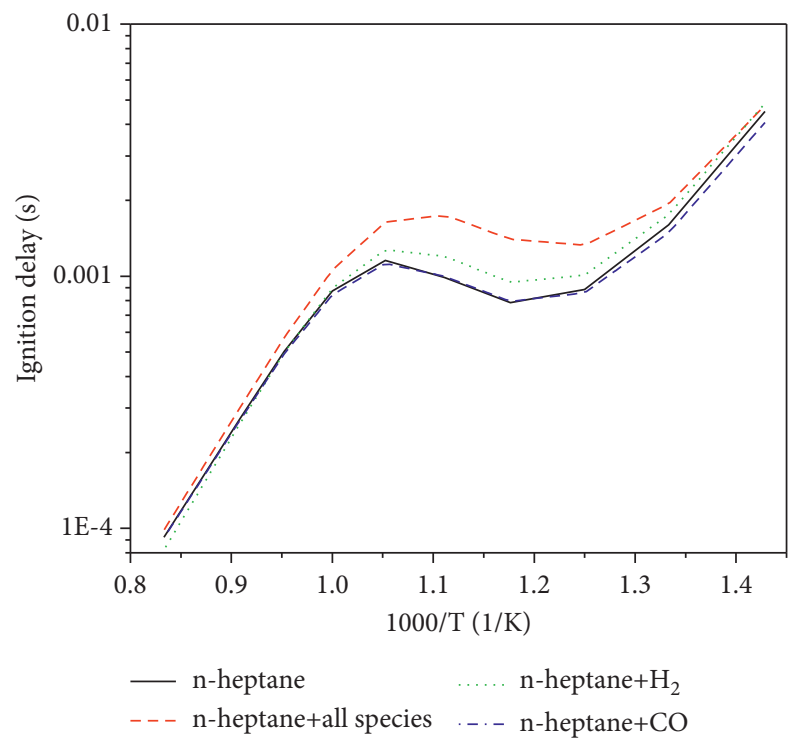

Figure 8: Ignition delay time of mixtures of different reforming species and $n$-heptane.

slightly for the mixture of $\mathrm{n}$-heptane and $\mathrm{CO}$, which is also consistent with the results in section 3.3.1.

Figure 9 shows the effects of $\mathrm{CO}, \mathrm{H}_{2}$, and all species on n-heptane laminar flame speed. It can be seen that the laminar flame speed could be increased by adding $\mathrm{H}_{2}$ and $\mathrm{CO}$ mixed with n-heptane. The laminar flame speed of $\mathrm{n}$-heptane $+\mathrm{CO}$ is obviously greater than that of n-heptane $+\mathrm{H}_{2}$. In order to delineate the mechanism by which $\mathrm{CO}$ and $\mathrm{H}_{2}$ increase the laminar flame speed of n-heptane, the concentration distribution of $\mathrm{O}, \mathrm{H}$, and $\mathrm{OH}$ radicals in the laminar flame speed was analyzed, and the results are shown Figure 10.

Figure 10 shows the axial distributions of $\mathrm{O}, \mathrm{H}$, and $\mathrm{OH}$ radicals in the laminar flame of different reforming mixtures and n-heptane. In the process of fuel combustion, $\mathrm{O}, \mathrm{H}$, and $\mathrm{OH}$ radicals are important free radicals that affect the fuel combustion and oxidation process because of their high

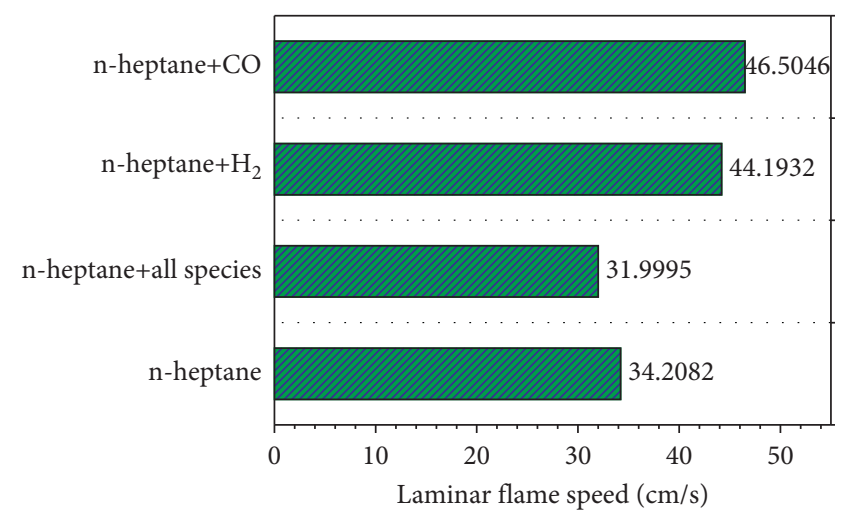

FIGURE 9: Laminar flame speed of mixtures of different reforming species and n-heptane.

activity. It can be seen from the proposed mechanism, whereby $\mathrm{H}_{2}$ and $\mathrm{CO}$ promote n-heptane combustion, that both of them increase the mole fraction of $\mathrm{O}, \mathrm{H}$, and $\mathrm{OH}$ in the combustion laminar flame. The free radical concentration distribution of $\mathrm{n}$-heptane $+\mathrm{CO}$ is significantly higher than that of $n$-heptane $+\mathrm{H}_{2}$. The difference between the promoting effects of $\mathrm{H}_{2}$ and $\mathrm{CO}$ on n-heptane combustion is mainly due to the different elementary reactions. In Figure 10(b), it can be seen that the mole fraction of $\mathrm{n}$-heptane + all species is higher than the mole fraction of $\mathrm{H}$ radical in pure heptane. The rate of production (ROP) of $\mathrm{O}$, $\mathrm{H}$, and $\mathrm{OH}$ radicals of the main reactions of $\mathrm{n}$-heptane + all species is shown in Figure 11. The main reactions of $\mathrm{H}$ radical formation are $\mathrm{R} 2: \mathrm{O}+\mathrm{H}_{2}=\mathrm{H}+\mathrm{OH}, \mathrm{R} 3: \mathrm{OH}+\mathrm{H}_{2}=$ $\mathrm{H}+\mathrm{H}_{2} \mathrm{O}$, and $\mathrm{R} 24: \mathrm{CO}+\mathrm{OH}=\mathrm{CO}_{2}+\mathrm{H}$. Therefore, both $\mathrm{H}_{2}$ and $\mathrm{CO}$ can promote the formation of $\mathrm{H}$. However, the laminar flame speed of $n$-heptane + all species is lower than that of pure heptane, because the dilution and thermodynamic effects of the reforming species are greater than the chemical effect.

The effect of $\mathrm{CO}, \mathrm{H}_{2}$, and all species on the adiabatic flame temperature of $n$-heptane is shown in Figure 12. It can be seen that the adiabatic flame temperature is increased by adding $\mathrm{H}_{2}$ and $\mathrm{CO}$. The addition of all species reduces the adiabatic flame temperature of pure n-heptane. According to the analysis of laminar flame speed, the addition of CO and $\mathrm{H}_{2}$ promotes the formation of $\mathrm{H}$, which in turn can promote the formation of other radicals, resulting in an increase of adiabatic flame temperature.

3.3.3. Emission Characteristics. The unburned hydrocarbon emission of the HCCI engine is high. Therefore, we analyzed the influence of reforming species on the unburned hydrocarbon emissions of the n-heptane HCCI engine. The addition of reforming species modifies the reaction path of the HCCI engine with n-heptane as fuel, so the emissions from the engine will also be affected. In this study, the effects of reforming species on the emissions of acetylene $\left(\mathrm{C}_{2} \mathrm{H}_{2}\right)$, ethylene $\left(\mathrm{C}_{2} \mathrm{H}_{4}\right)$, propyne $\left(\mathrm{C}_{3} \mathrm{H}_{4}-\mathrm{P}\right)$, allene $\left(\mathrm{C}_{3} \mathrm{H}_{4}-\mathrm{A}\right)$, propene $\left(\mathrm{C}_{3} \mathrm{H}_{6}\right)$, and 1,3-butadiene $\left(\mathrm{C}_{4} \mathrm{H}_{6}\right)$ were analyzed. Figure 13 shows the effects of the addition of $\mathrm{H}_{2}, \mathrm{CO}$, and all reforming species on the mole fraction of hydrocarbon 


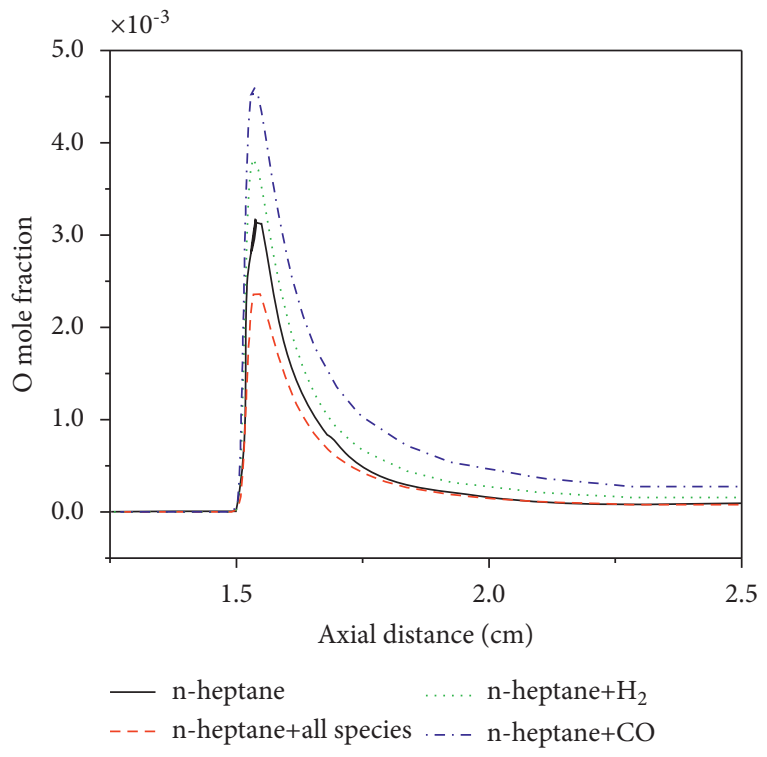

(a)

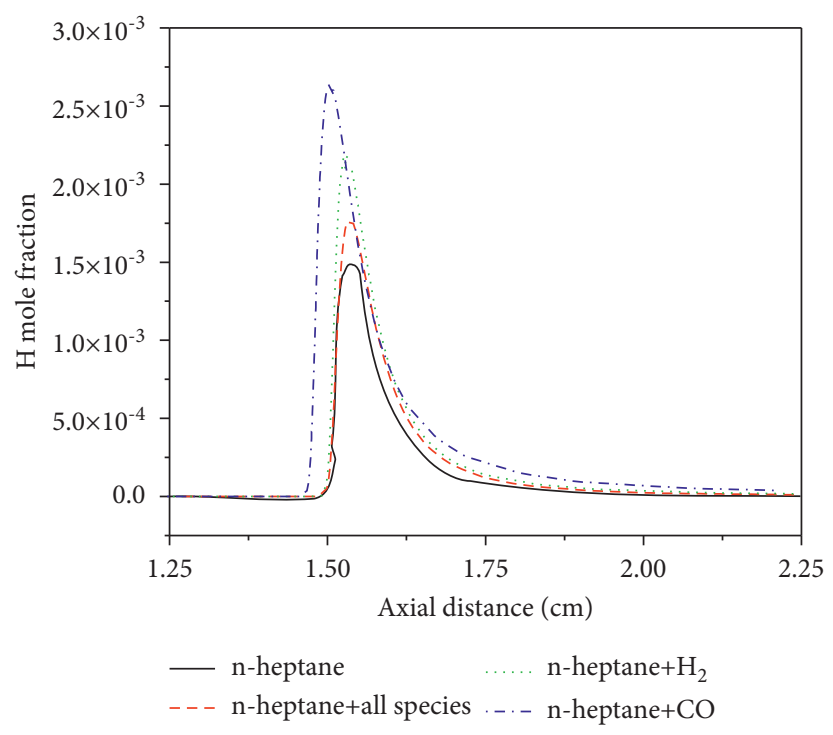

(b)

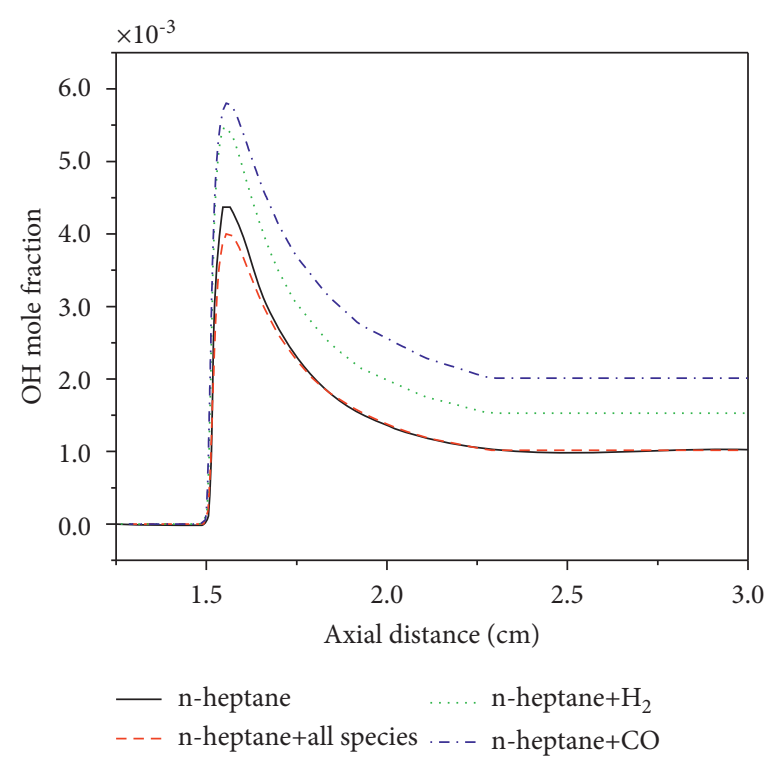

(c)

FIgURE 10: Axial distributions of $\mathrm{O}, \mathrm{H}$, and $\mathrm{OH}$ radicals in laminar flame of different reforming species and n-heptane.

emissions. It can be seen that the addition of all reforming species significantly reduces the peak mole fractions of $\mathrm{C}_{2} \mathrm{H}_{2}$, $\mathrm{C}_{2} \mathrm{H}_{4}, \mathrm{C}_{3} \mathrm{H}_{4}-\mathrm{P}, \mathrm{C}_{3} \mathrm{H}_{4}-\mathrm{A}, \mathrm{C}_{3} \mathrm{H}_{6}$, and $\mathrm{C}_{4} \mathrm{H}_{6}$, but the mole fraction of $\mathrm{C}_{2} \mathrm{H}_{2}$ increases in the later stage of combustion compared with the combustion of pure n-heptane. The addition of $\mathrm{H}_{2}$ increases the peak mole fraction of $\mathrm{C}_{2} \mathrm{H}_{2}$ and $\mathrm{C}_{3} \mathrm{H}_{4}-\mathrm{P}$. The addition of $\mathrm{CO}$ has little effect on the peak mole fraction of hydrocarbon emission, but the mole fractions of $\mathrm{C}_{3} \mathrm{H}_{4}-\mathrm{P}$ and $\mathrm{C}_{3} \mathrm{H}_{4}-\mathrm{A}$ increase in the later stage of combustion compared with the combustion of pure n-heptane.

Figure 14 shows the effect of adding $\mathrm{H}_{2}, \mathrm{CO}$, and all reforming species on NOx emissions from an HCCI engine. The simulation results show that adding $\mathrm{H}_{2}$ and $\mathrm{CO}$ will increase the NOx emissions from the engine, due to the abovementioned increased temperature in the cylinder. The addition of all reforming species will reduce the temperature in the cylinder and reduce NOx emissions. Therefore, fuel reforming can reduce NOx emissions from the HCCI engine.

Figure 15 shows the effect of adding $\mathrm{H}_{2}, \mathrm{CO}$, and all reforming species on $\mathrm{CO}$ emissions from the HCCI engine. It can be seen that the concentration of $\mathrm{CO}$ is very high in the initial stage, because the reforming species include $\mathrm{CO}$. The addition of $\mathrm{H}_{2}$ also leads to a slight increase in $\mathrm{CO}$ emission. This may be due to its diluting effect results in a decrease in oxygen concentration and incomplete combustion. The addition of $\mathrm{CO}$ will clearly increase its initial concentration and hence the emission of $\mathrm{CO}$ in the later stage of combustion. As mentioned above, the addition of reforming species results in a decrease in in-cylinder temperature and 


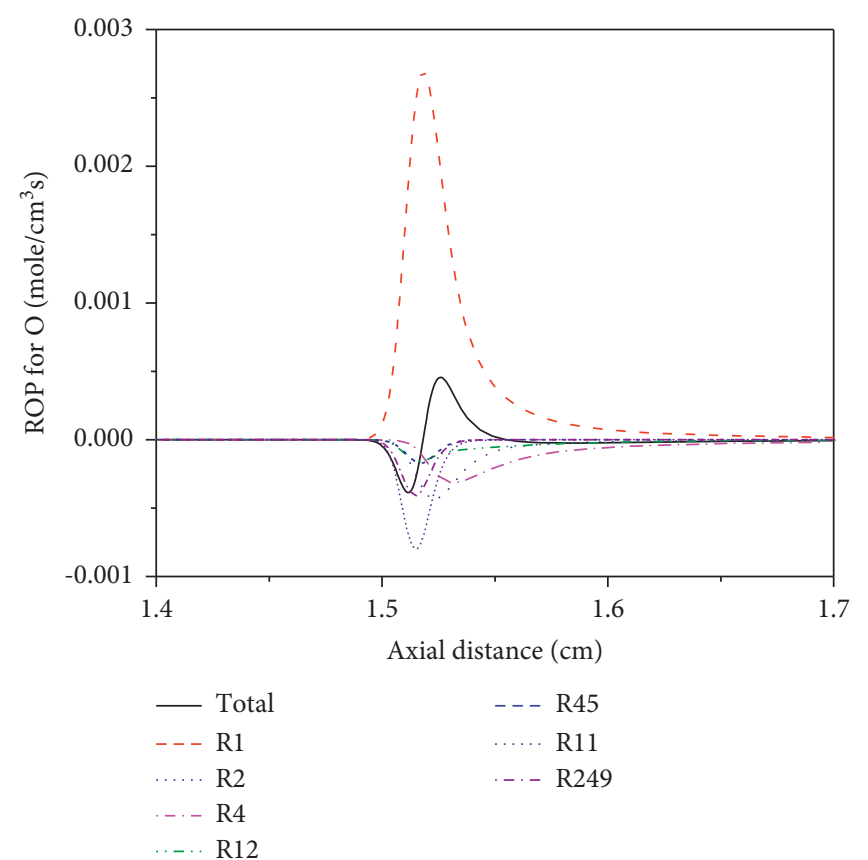

(a)

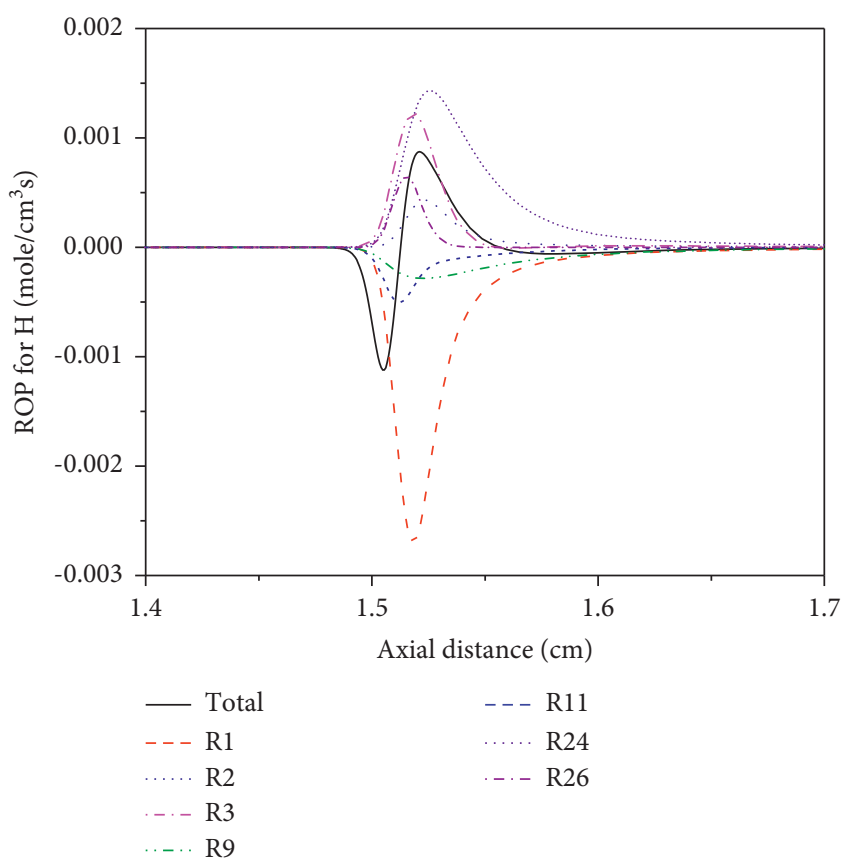

(b)

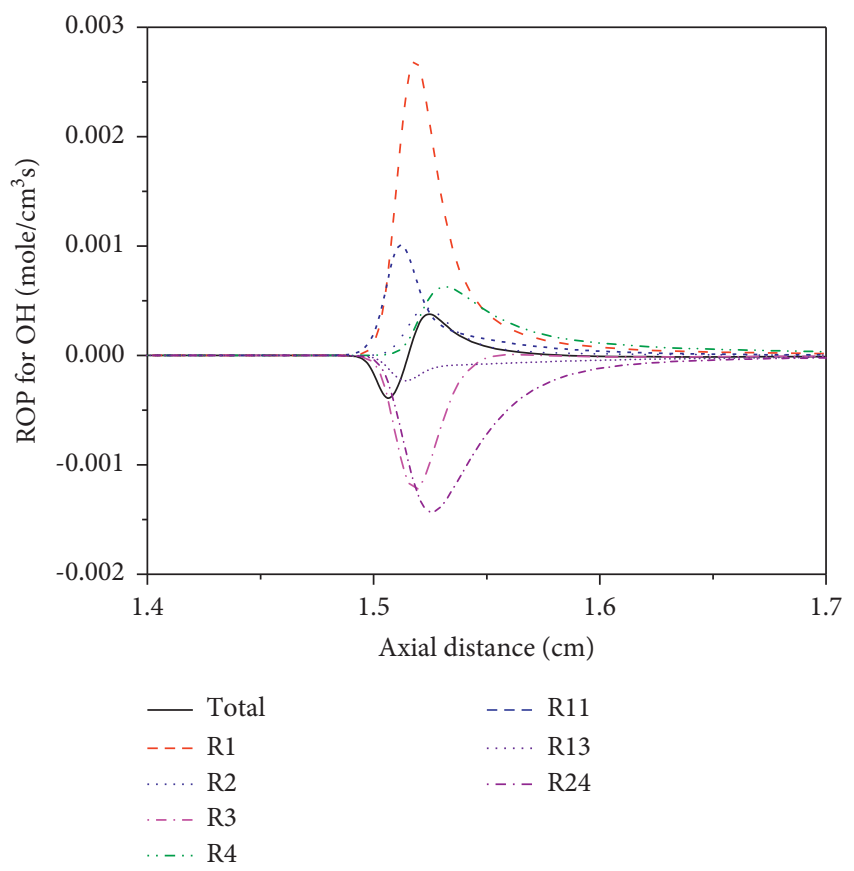

(c)

FIGURE 11: Axial distributions of ROP for $\mathrm{O}, \mathrm{H}$, and $\mathrm{OH}$ radicals through the key reactions in laminar flame of different reforming species and n-heptane.

incomplete combustion. Incomplete combustion will lead to increased $\mathrm{CO}$ emissions when the exhaust valve is opened.

On this basis, appropriate strategies for improving HCCI engine performance and reducing emissions are proposed. This strategy is a special cylinder without a complex control system, which is used for fuel enrichment and reforming and can provide part of the power for the engine. Compared with other reforming strategies, it avoids additional reforming units (reaction catalytic units) and saves engine layout space. Besides, in addition to diesel, other fuels can also be used for HCCI engines. It was found that the addition of a reforming component delays the combustion stage of n-heptane, which provides a method to control engine performance. Fuel reforming can also reduce emissions. Moreover, the simulation results showed that in-cylinder fuel reforming can effectively improve engine combustion and emission characteristics. Furthermore, future studies will examine the effects of in-cylinder reforming for different types of fuels on HCCI engine performance. 


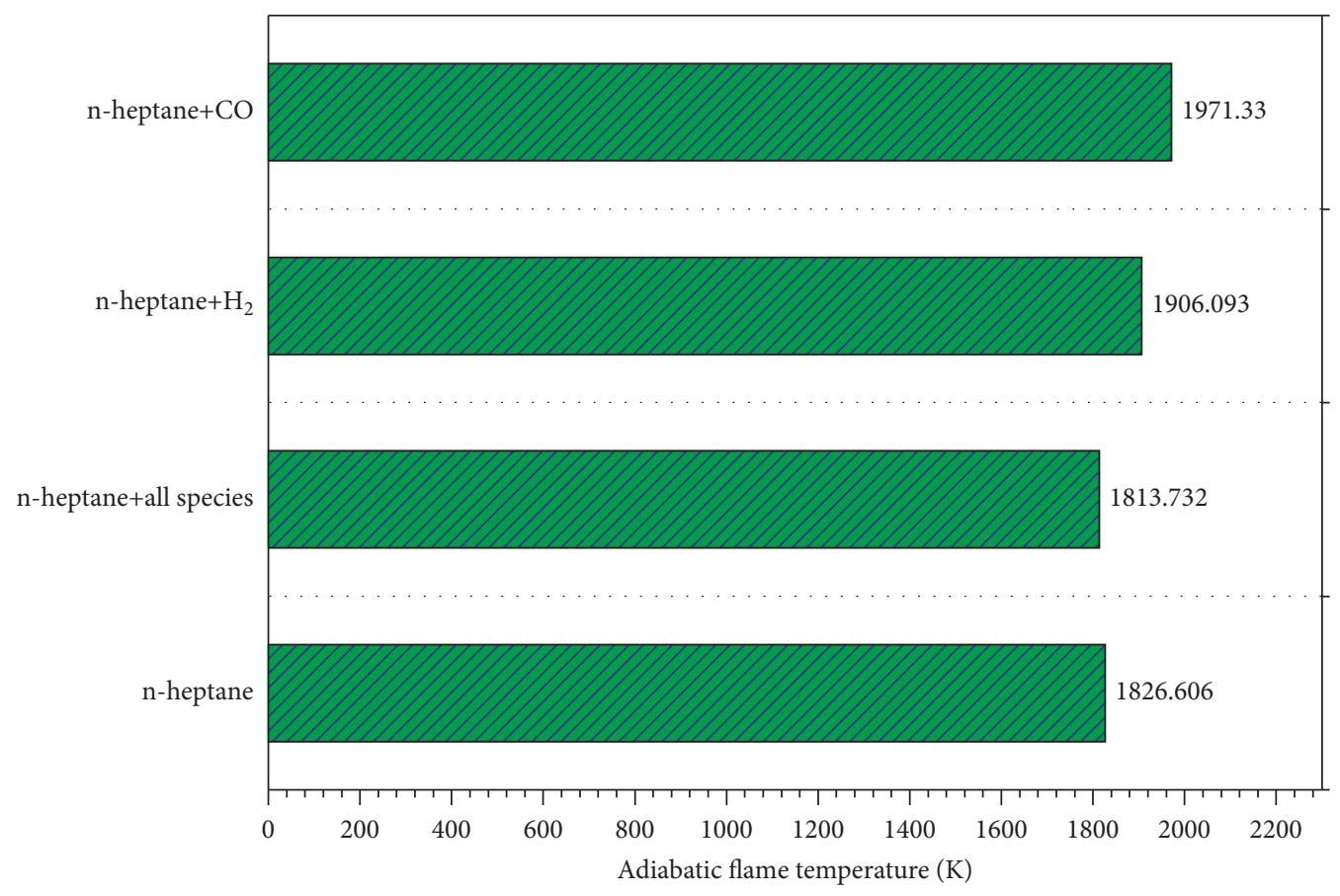

Figure 12: Adiabatic flame temperature of mixtures of different reforming species and n-heptane.

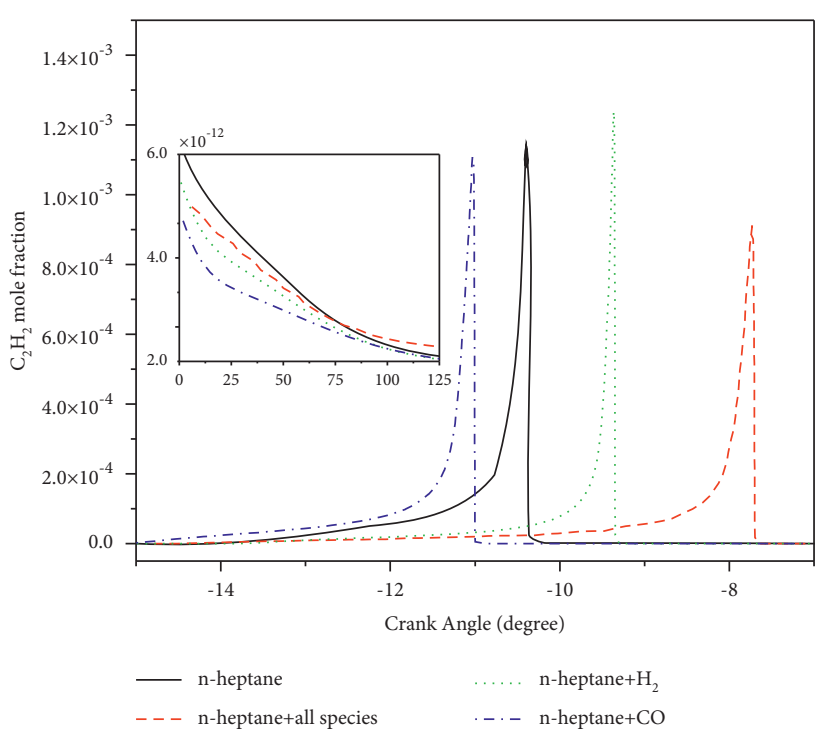

(a)

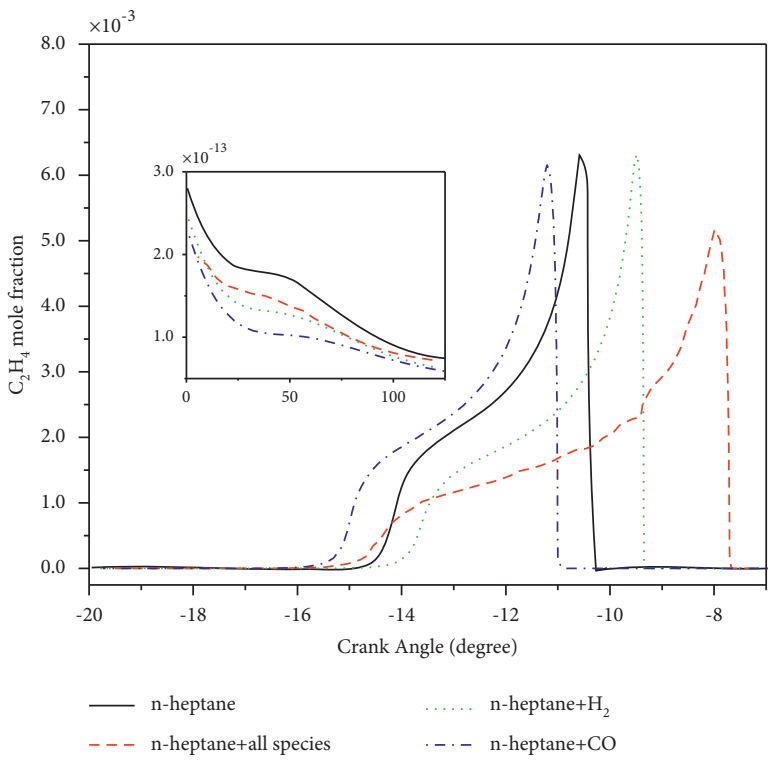

(b)

FIGURE 13: Continued. 


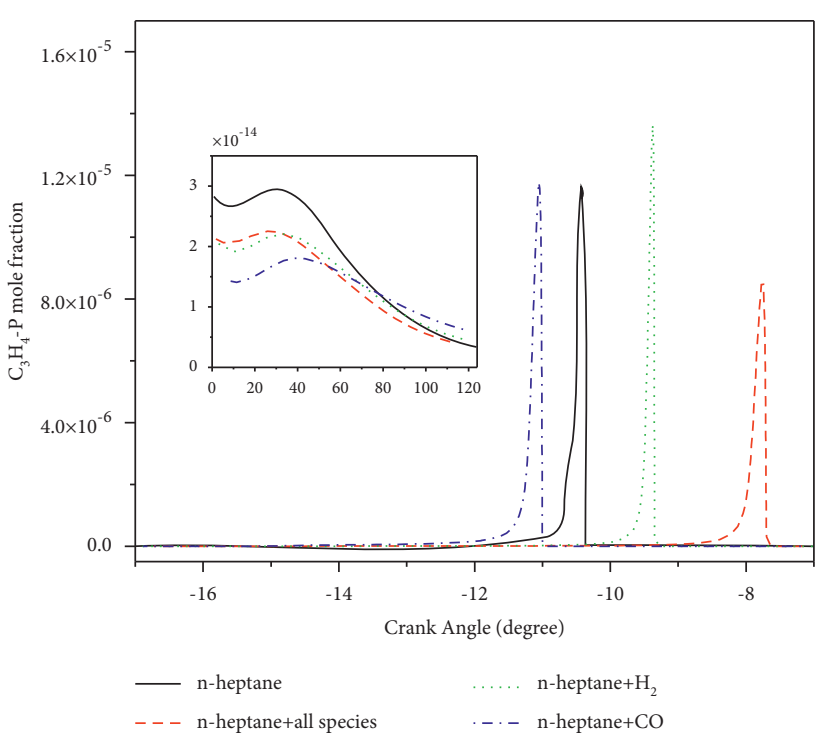

(c)

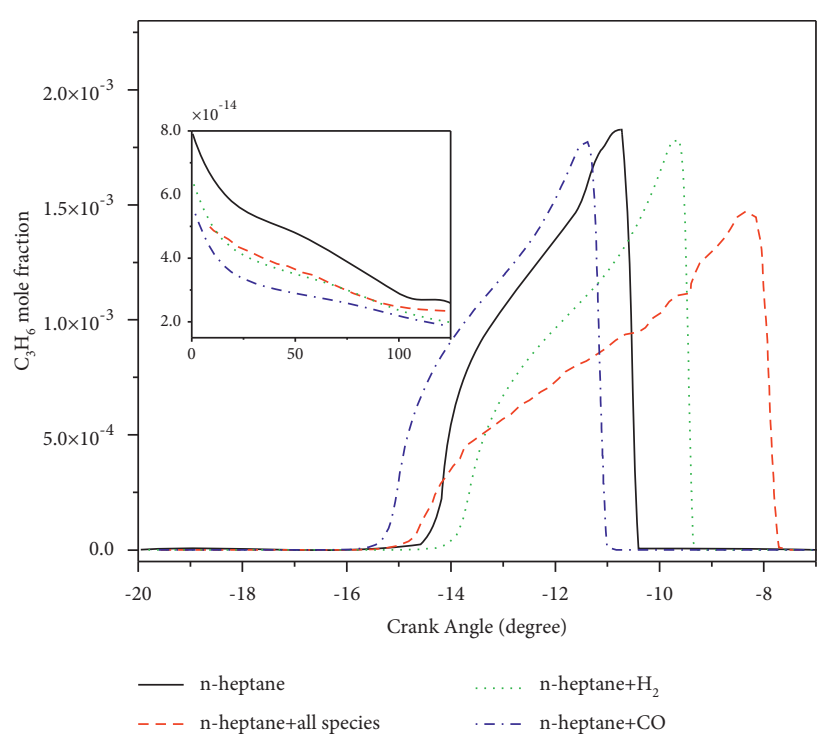

(e)

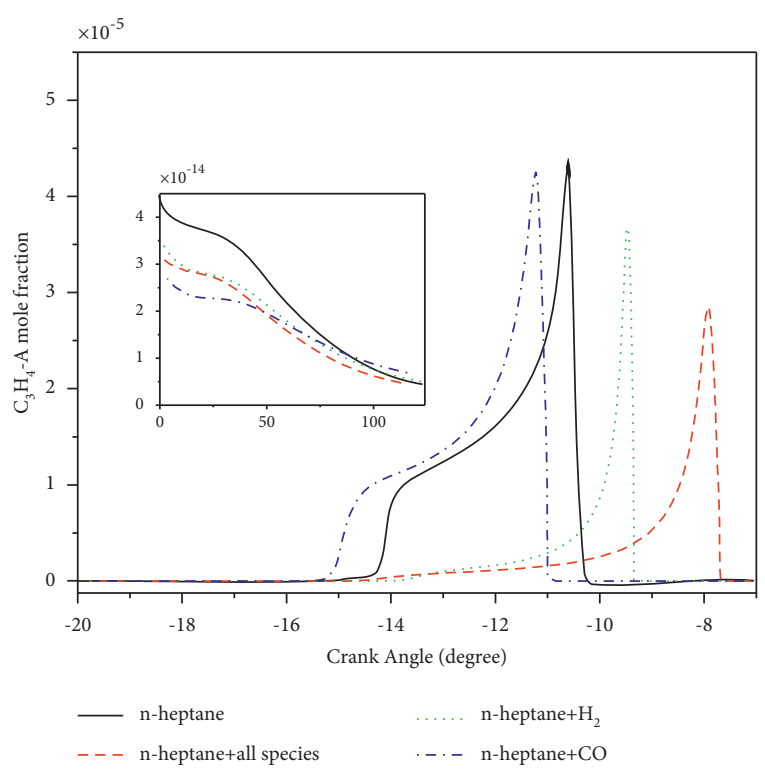

(d)

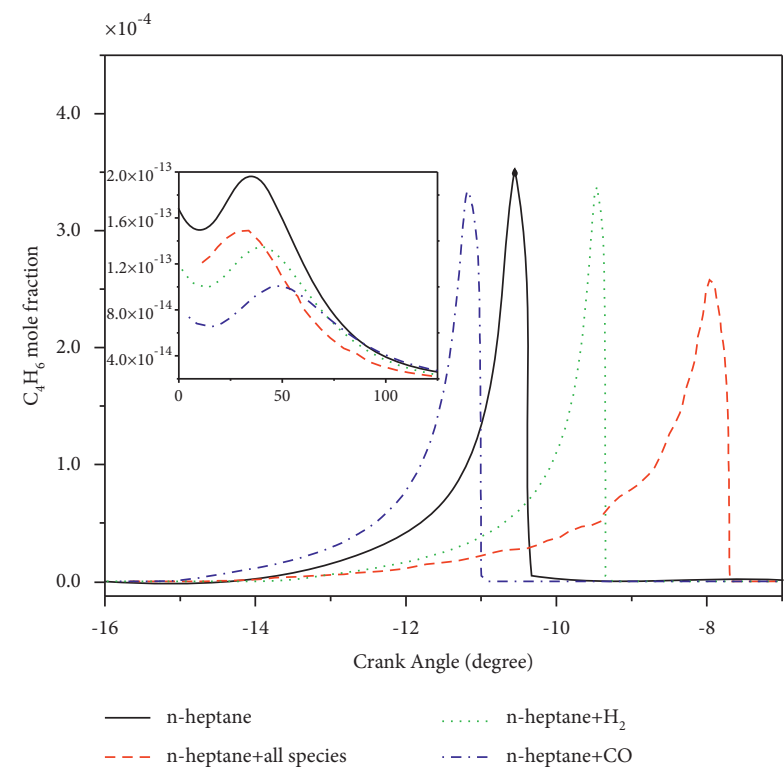

(f)

FIGURE 13: Distributions of hydrocarbons in different reforming mixtures in the normal cylinder. 


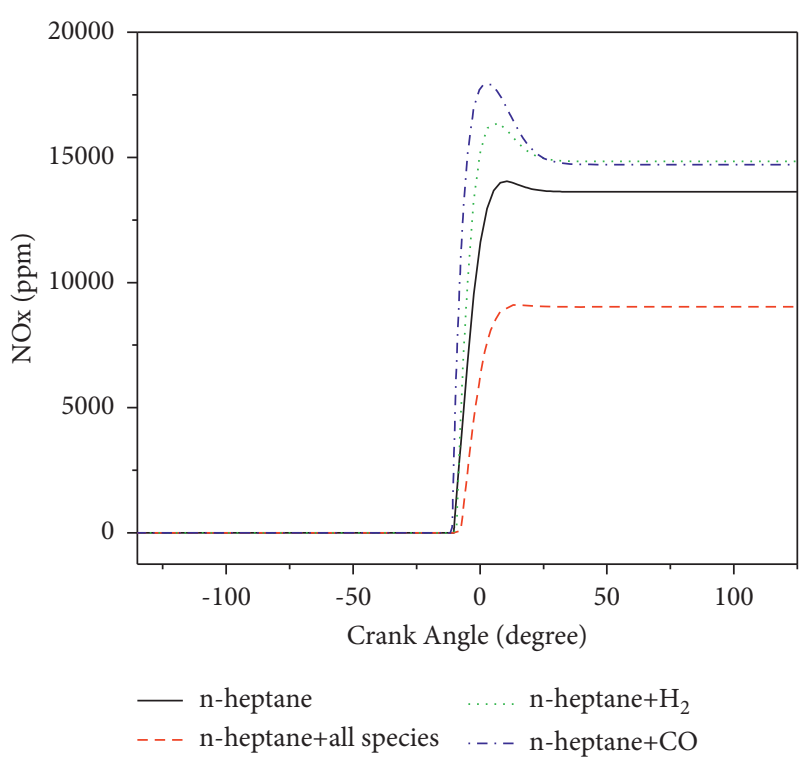

Figure 14: Effects of different reforming species on NOx emissions from the normal cylinder.

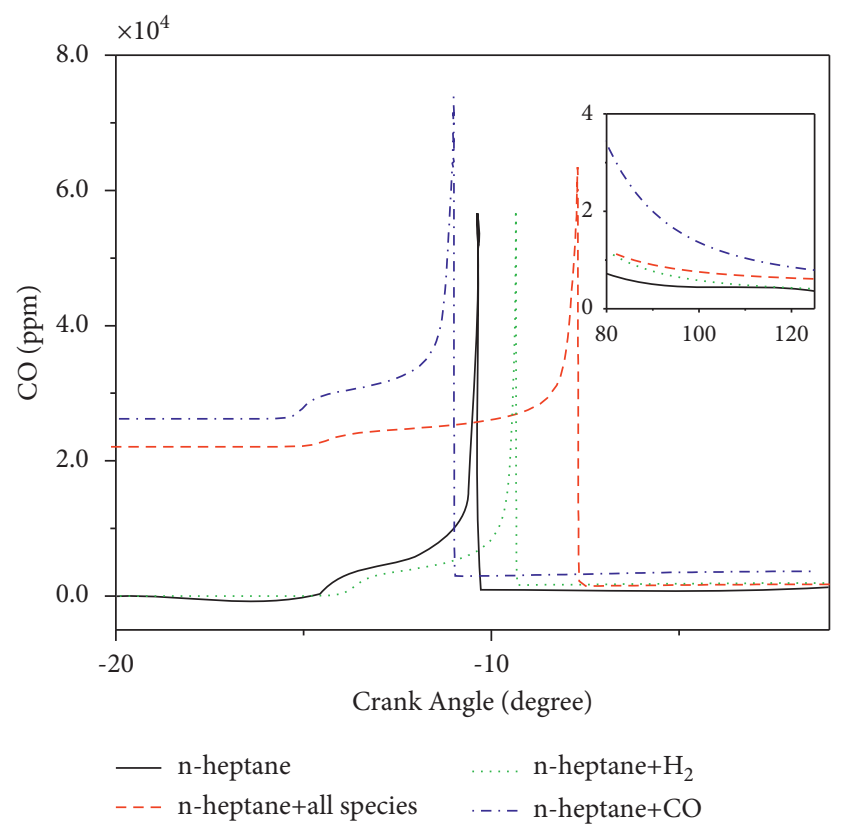

Figure 15: Effects of different reforming species on $\mathrm{CO}$ emission from the normal cylinder.

\section{Conclusions}

The effects of $n$-heptane enrichment on in-cylinder fuel reforming characteristics and HCCI engine performance have been studied by numerical simulation. Besides, the effects of reforming species on the combustion of $n$-heptane have been analyzed through detailed mechanistic considerations. The main conclusions drawn are as follows:

(1) The enrichment of $\mathrm{n}$-heptane can produce sufficient $\mathrm{H}_{2}$ and $\mathrm{CO}$, while the hydrocarbon content of reforming species is low. By comparing different equivalence ratios of $n$-heptane in the reforming cylinder, the appropriate equivalence ratio of the optimal value has been determined.

(2) The addition of reforming species retards the ignition delay time and the combustion phase, which serves to improve the performance of the HCCI engine. Besides, the addition of $\mathrm{H}_{2}$ retards the combustion phase of the HCCI engine due to the dilution and thermodynamic effects, and its chemical effect through the reaction $\mathrm{OH}+\mathrm{H}_{2}=\mathrm{H}+\mathrm{H}_{2} \mathrm{O}$, which consumes $\mathrm{OH}$ radicals and retards the lowtemperature reaction of $\mathrm{n}$-heptane. The addition of $\mathrm{CO}$ to $\mathrm{n}$-heptane fuel advances the combustion phase of the HCCI engine. Although CO had diluting and thermodynamic effects, its chemical effect is more significant, producing more free radicals through the reaction $\mathrm{CO}+\mathrm{O}_{2}=\mathrm{CO}_{2}+\mathrm{O}$, thereby promoting the low-temperature reaction of n-heptane.

(3) $\mathrm{H}_{2}$ and $\mathrm{CO}$ increased the laminar flame speed and adiabatic flame temperature of n-heptane. Both $\mathrm{H}_{2}$ and $\mathrm{CO}$ promoted in-cylinder combustion in the $\mathrm{n}$-heptane HCCI engine, increasing the combustion temperature and pressure in the cylinder. However, the addition of all reforming species reduces the peak pressure and temperature in the cylinder.

(4) The different effects of reforming species on HCCI combustion of $n$-heptane have been studied including their chemical, dilution, and thermodynamic effects. The results showed that the dilution and thermodynamic effects of reforming species on $\mathrm{n}$-heptane are more significant than the chemical effect.

(5) Fuel reforming reduces the emission of $\mathrm{C}_{2} \mathrm{H}_{4}, \mathrm{C}_{3} \mathrm{H}_{4}$ $\mathrm{P}, \mathrm{C}_{3} \mathrm{H}_{4}-\mathrm{A}, \mathrm{C}_{3} \mathrm{H}_{6}, \mathrm{C}_{4} \mathrm{H}_{6}$, and NOx. However, it increases the emissions of $\mathrm{C}_{2} \mathrm{H}_{2}$ and $\mathrm{CO}$.

\section{Data Availability}

No data were used to support this study.

\section{Conflicts of Interest}

The authors declare that there are no conflicts of interest regarding the publication of this study.

\section{Acknowledgments}

This work was supported by the National Natural Science Foundation of China (grant number U1906232).

\section{References}

[1] R. D. Reitz, "Directions in internal combustion engine research," Combustion and Flame, vol. 160, no. 1, pp. 1-8, 2013.

[2] G. Kalghatgi, "Is it really the end of internal combustion engines and petroleum in transport?" Applied Energy, vol. 225, pp. 965-974, 2018. 
[3] N. Rituraj and T. A. Kumar, "The toxicological mechanisms of environmental soot (Black Carbon) and carbon black: focus on oxidative stress and inflammatory pathways," Frontiers in Immunology, vol. 8, p. 763, 2017.

[4] M. Yao, Z. Zheng, and H. Liu, "Progress and recent trends in homogeneous charge compression ignition (HCCI) engines," Progress in Energy and Combustion Science, vol. 35, no. 5, pp. 398-437, 2009.

[5] R. D. Reitz and G. Duraisamy, "Review of high efficiency and clean reactivity controlled compression ignition (RCCI) combustion in internal combustion engines," Progress in Energy and Combustion Science, vol. 46, pp. 12-71, 2015.

[6] K. Cho, Z. Yu, and D. Cleary, "Investigation of fuel effects on combustion robustness/stability of partially premixed compressionignition (PPCI) combustion mode," SAE Tech Pap, 2018.

[7] R. G. Papagiannakis, C. D. Rakopoulos, D. T. Hountalas, and D. C. Rakopoulos, "Emission characteristics of high speed, dual fuel, compression ignition engine operating in a wide range of natural gas/diesel fuel proportions," Fuel, vol. 89, no. 7, pp. 1397-1406, 2010.

[8] N. Yilmaz and T. M. Sanchez, "Analysis of operating a diesel engine on biodiesel-ethanol and biodiesel-methanol blends," Energy, vol. 46, no. 1, pp. 126-129, 2012.

[9] D. N. Assanis, P. M. Najt, J. E. Dec, T. N. Asmus, and F. Zhao, "Homogeneous charge compression ignition (HCCI) engines," SAE Tech Pap, 2003.

[10] B.-Q. He, J. Yuan, M.-B. Liu, and H. Zhao, "Combustion and emission characteristics of a n-butanol HCCI engine," Fuel, vol. 115, pp. 758-764, 2014.

[11] G. Coskun, H. S. Soyhan, U. Demir, A. Turkcan, A. N. Ozsezen, and M. Canakci, "Influences of second injection variations on combustion and emissions of an HCCIDI engine: experiments and CFD modelling," Fuel, vol. 136, pp. 287-294, 2014.

[12] M. Zheng, X. Han, U. Asad, and J. Wang, "Investigation of butanol-fuelled HCCI combustion on a high efficiency diesel engine," Energy Conversion and Management, vol. 98, pp. 215-224, 2015.

[13] H. Guo and W. S. Neill, "The effect of hydrogen addition on combustion and emission characteristics of an n-heptane fuelled HCCI engine," International Journal of Hydrogen Energy, vol. 38, no. 26, pp. 11429-11437, 2013.

[14] Y. Cui, C. Geng, H. Liu, Z. Zheng, and M. Yao, "Investigations on the effects of low temperature reforming of n-heptane/nbutanol blends on the flame development progress and combustion chemical kinetics," Fuel, vol. 290, Article ID 120001, 2021.

[15] Y. Huang, C. J. Sung, and J. A. Eng, "Effects of n-butane addition on reformer gas combustion: implications for the potential of using reformer gas for an engine cold start," Proceedings of the Combustion Institute, vol. 29, no. 1, pp. 759-765, 2002.

[16] E. D. Sail, D. A. Morgenstern, J. P. Fornango, J. W. Taylor, N. Chomic, and J. Wheeler, "Reforming of ethanol with exhaust heat at automotive scale," Energy Fuel, vol. 27, no. 9, pp. 5579-5588, 2013.

[17] G. Chao, H. Liu, X. Ran, and M. Yao, "The impact of low temperature reforming (LTR) products of fuel-rich $n$-heptane on compression ignition engine combustion," Fuel, vol. 229, pp. 11-21, 2018.

[18] C. D. Yao, X. C. Li, C. Tang, R. Z. Zang, and Y. Wu, "Combustion characteristic of methanol dissociated gas engine through $\mathrm{Cu} / \mathrm{Pd}$-based catalysts," Transactions of Chinese
Society for Internal Combustion Engines, vol. 30, no. 6, pp. 486-491, 2012.

[19] D. Yap, S. Peucheret, A. Megaritis, M. Wyszynski, and H. Xu, "Natural gas HCCI engine operation with exhaust gas fuel reforming," International Journal of Hydrogen Energy, vol. 31, no. 5, pp. 587-595, 2006.

[20] Z. Xu, L. Zhu, Z. He, A. Li, Y. Shao, and Z. Huang, "Performance optimization of in-cylinder thermochemical fuel reforming (TFR) with compression ratio in an SI natural gas engine," Fuel, vol. 203, pp. 162-170, 2017.

[21] T. Alger and B. Mangold, "Dedicated EGR: a new concept in high efficiency engines," SAE Tech Pap, 2009.

[22] T. Alger, B. Mangold, C. Roberts, and J. Gingrich, "The interaction of fuel anti-knock index and cooled EGR on engine performance and efficiency," SAE Tech Pap, 2012.

[23] Q. Sun, B. Li, A. Li et al., "Insight into fuel reactivity effects on thermochemical fuel reforming (TFR)," International Journal of Hydrogen Energy, vol. 45, no. 15, pp. 9010-9024, 2020.

[24] L. Zhu, Z. He, Z. Xu, X. Lu, J. Fang, and W. Zhang, "Incylinder thermochemical fuel reforming (TFR) in a sparkignition natural gas engine," Proceedings of the Combustion Institute, vol. 36, no. 3, pp. 3487-3497, 2016.

[25] Y. Wang, L. Wei, and M. Yao, "A theoretical investigation of the effects of the low-temperature reforming products on the combustion of $\mathrm{n}$-heptane in an HCCI engine and a constant volume vessel," Applied Energy, vol. 181, pp. 132-139, 2016.

[26] J. Willand, R. G. Nieberding, G. Vent, and C. Enderle, "The knocking syndrome: its cure and potential," SAE Tech Pap, 1998.

[27] T. Urushihara, K. Hiraya, A. Kakuhou, and T. Itoh, "Expansion of HCCI operating region by the combination of direct fuel injection, negative valve overlap and internal fuel reformation," SAE Tech Pap, 2003.

[28] F. Maroteaux, "Development of a two-part n-heptane oxidation mechanism for two stage combustion process in internal combustion engines," Combustion and Flame, vol. 186, pp. 1-16, 2017.

[29] Physical and Life Sciences Directorate. n-Heptane, Detailed Mechanism, Version 3.1, Lawrence Livermore National Laboratory, Livermore, CA, USAhttps://www-pls.llnl.gov/? url=science_and_technology-chemistry-combustion-n_ heptane_version_3 LLNL-MI-536391.

[30] M. Bergman and V. I. Golovitchev, "Application of transient temperature vs. equivalence ratio emission maps to engine simulations," SAE Tech Pap, 2007.

[31] R. J. Kee, F. M. Rupley, and J. A. Miller, "ANSYS CHEMKIN 17.0,” ANSYS Reaction Design, San Diego, CA, USA, 2016.

[32] W. Feng, Z. Zheng, and Z. He, "Reduced polycyclic aromatic hydrocarbon formation chemical kinetic model of diesel surrogate fuel for homogeneous charge compression ignition combustion," Energy \& Fuels, vol. 26, pp. 1612-1620, 2012.

[33] P. Konsereeparp and M. D. Checkel, "Study of reformer gas effects on $n$-heptane HCCI combustion using a chemical kinetic mechanism optimized by genetic algorithm," SAE Tech Pap, 2008.

[34] E. Neshat, R. K. Saray, and S. Parsa, "Numerical analysis of the effects of reformer gas on supercharged n-heptane HCCI combustion," Fuel, vol. 200, pp. 488-498, 2017. 